\title{
LA PONDERACIÓN Y LA NEUTRALIDAD ABIERTA CONTRA LA DISCRIMINACIÓN RELIGIOSA Y RACIAL EN LA DECISIÓN DEL TRIBUNAL CONSTITUCIONAL ALEMÁN DE 2015 SOBRE EL USO DEL VELO POR PROFESORAS
}

MARÍA ELÓSEGUI ITXASO 
SUMARIO

I. INTRODUCCIÓN. EL CLIMA ACTUAL EN EL QUE EL TRIBUNAL CONSTITUCIONAL FEDERAL ALEMÁN FALLA ESTA DECISIÓN. II. LA PONDERACIÓN EN LA DECISIÓN DEL BVERFG DE 2015 SOBRE EL USO DEL VELO POR MAESTRAS. III. LOS HECHOS Y LA LEY DE EDUCACIÓN DE RENANIA DEL NORTE WESTFALIA. IV. LOS ARGUMENTOS DEL BVERFG EN LOS FUNDAMENTOS DE DERECHO. V. LOS DERECHOS DE LAS RECURRENTES. V. 1. El derecho de libertad religiosa de los funcionarios en las escuelas públicas y el uso de prendas religiosas en ese espacio. V. 2. El acceso en igualdad a la función pública y la discriminación de las mujeres musulmanas. VI. EL OTRO LADO DE LA BALANZA: LOS DERECHOS DE TERCEROS. EXAMEN DE LOS LÍMITES A LOS DERECHOS FUNDAMENTALES EN EL CASO PRESENTADO. PELIGRO CONCRETO VERSUS PELIGRO ABSTRACTO. VI.1. La libertad religiosa negativa de los alumnos y el límite de prohibición de adoctrinamiento por parte de los profesores. VI.2. El derecho de los padres (art. 6. 1 lf). VI.3. El principio de neutralidad abierta de la educación estatal y el trato paritario de las religiones. VII. EL EXAMEN DE CONSTITUCIONALIDAD DEL ARTÍCULO 57 DE LA LEY DE EDUCACIÓN DE RENANIA DEL NORTE WESTFALIA. VII.1. Interpretación restrictiva del inciso 1 del art. 57.4., sólo ante peligro concreto. VII.2. Análisis del inciso 2 del art. 57.4 SchulG RNW. VII.3. La cláusula de privilegio de los valores cristianos y occidentales del art. 57.4.3 SchulG RNW. VII.4. Discusión sobre el artículo 7 párrafo 1 y artículo 12.3 de la Constitución de Renania del Norte Westfalia. VII.5. Los trabajos legislativos previos. VIII. CONCLUSIONES. 


\title{
LA PONDERACIÓN Y LA NEUTRALIDAD ABIERTA CONTRA LA DISCRIMINACIÓN RELIGIOSA Y RACIAL EN LA DECISIÓN DEL TRIBUNAL CONSTITUCIONAL ALEMÁN DE 2015 SOBRE EL USO DEL VELO POR PROFESORAS
}

\author{
MARÍA ELÓSEGUI ITXASO \\ Catedrática de Filosofía del Derecho ${ }^{1}$ \\ Universidad de Zaragoza (en situación de Servicios Especiales) \\ Jueza del Tribunal Europeo de Derechos Humanos del Consejo \\ de Europa en Estrasburgo
}

\section{INTRODUCCIÓN. EL CLIMA ACTUAL EN EL QUE EL TRIBUNAL CONSTITUCIONAL ALEMÁN FALLA ESTA DECISIÓN}

El objetivo del artículo se centra en un análisis de la resolución del Tribunal Constitucional alemán del 27 de enero de $2015^{2}$, sobre la prohibición del uso del velo islámico a dos profesoras contratadas en el Land de Renania del Norte-Westfalia (a partir de ahora el Land será citado como RNW) ${ }^{3}$.

\footnotetext{
${ }^{1}$ Facultad de Derecho. Universidad de Zaragoza. Calle Pedro Cerbuna, 12, 50009 Zaragoza. E-mail: elosegui@unizar.es

Publicaciones en: http://www.intercultural.unizar.es

2 BVerfG, Beschluss, 27.01.2015, disponible en https://www.bundesverfassungsgericht.de/ SharedDocs/Entscheidungen/DE/2015/01/rs20150127_1bvr047110.html

La diferencia entre una resolución y una sentencia del BVerfG es que las Resoluciones (Beschliusse) son adoptadas sin audiencia pública, a diferencia de las Sentencias (Urteile). La mayor parte de las decisiones son resoluciones. BENDA/KLEIN (2001) (2. ${ }^{a}$ edición), Verfassungsprozessrecht. Ein Lehr-und Handbuch, München, C.F. Müller, p. 128.

Agradezco al profesor Dr. Martin Boroswski su cálida acogida en la Facultad de Derecho de la Universidad Ruprecht-Karls de Heidelberg (en el Institut für Staatsrecht, Verfassungslehere und
} 
La resolución es un botón de muestra de un tema de fondo que va mucho más allá de la traída y llevada cuestión del uso del velo islámico por parte de algunas profesoras alemanas y su correspondiente extensa jurisprudencia. En realidad, detrás de está resolución late una discusión sobre el modelo de neutralidad del Estado alemán presente en la Ley Fundamental (LF) vigente desde 1949 y la integración de la diversidad religiosa.

En ocasiones se ha simplificado la cuestión estableciendo el debate del modelo de separación entre Iglesia y Estado entre dos posibilidades: la de la laicidad estricta a la francesa o el modelo alemán de neutralidad. Sin embargo, esto es un reduccionismo de la cuestión porque precisamente en Alemania se lleva discutiendo desde los años noventa y de un modo más agudo desde el año 2000, sobre la definición de cómo entender la neutralidad del espacio público en la actualidad, con la correspondiente separación entre Iglesia y Estado, pero compatible con su modelo de cooperación.

A mi juicio caben en realidad tres modelos o posibilidades de neutralidad en el contexto alemán ${ }^{4}$. Es crucial en este debate entender la propuesta de una tercera posibilidad que evita simplificar en una dualidad de blanco o negro ${ }^{5}$. Cabría una vuelta a un cierto confesionalismo privilegiado del cristianismo, así como dentro de los modelos de neutralidad se situarían la laicidad estricta o la neutralidad abierta.

Como ya he señalado en un artículo anterior: «En este debate se aúnan distintas polémicas, una se refiere al modelo constitucional de fondo sobre la interpretación del principio de la neutralidad ideológico-religiosa del Estado ante el fenómeno religioso en Alemania, en el que se aprecian distintas sensibilidades: quienes apoyan un modelo de cooperación (neutralidad positiva), pero reforzando la cooperación con las confesiones cristianas (protestantes y católicas) o la cultura dominante (Deutsche Leitkultur $)^{6}$ que acaba volviendo a una cierta confesionalidad de Estado, otros que

Rechtsphilosophie) durante los meses de abril, mayo y junio de 2017, así como al profesor Robert Alexy por sus nuevas sugerencias en relación con la mencionada Resolución de 2015. También me beneficié de diversos seminarios en el Max-Planck-Institut für ausländisches öffentliches Recht und Völkerrecht. Del mismo modo debo mi agradecimiento a la Asociación Alexander von Humboldt por su siempre generoso apoyo hacia todos los becarios de la Asociación, permitiéndonos hacer nuevas estancias de investigación en las universidades alemanas. Por último, me resta dejar constancia de mi gratitud a los o las evaluadores anónimos.

${ }^{4}$ El artículo se centra tan sólo en la bibliografía y jurisprudencia alemana. Conocedora de la jurisprudencia del Tribunal de Justicia de la Unión Europea, así como del Tribunal Europeo de Derechos Humanos, no se ha introducido expresamente ninguna referencia a los mismos porque ello requeriría más espacio y porque el objetivo marcado para esta investigación se ciñe a Alemania.

5 Esos modelos se reflejan igualmente en los distintos grupos personados en 2015 en el recurso de amparo ante el BVerfG en este nuevo caso.

${ }^{6}$ ISENSEE, J. (2010). "Integration mit Migrationshintergrund», en Juristenzeitung (JZ) 7, pp. 317-372. Sobre el concepto de «Deutsche Leitkultur», véase p. 320. El artículo es profundo, rico y de imprescindible lectura. Comparto algunos de sus razonamientos, pero nos separamos en las soluciones propuestas. Una discusión más detallada sobre la noción de Leitkultur y los planes de integración de la inmigración en Alemania en ELÓSEGUI, M. (2015). «La vuelta del concepto de Deutsche Leitkultur a raíz de los planes de integración de los inmigrantes en Alemania», en Revista de Estudios de Deusto: Revista 
aprovechan los conflictos para inclinar la balanza de la neutralidad hacia un modelo laicista en la línea del derecho francés ${ }^{7}$ (neutralidad estricta con distancia respecto a las religiones, strenge Neutralität Lösung o Distanz Neutralität ${ }^{8}$ ) y por último quienes refuerzan el modelo vigente de separación con cooperación amistosa, pero insistiendo en la necesidad de una nueva apertura y flexibilización hacia la presencia de las religiones minoritarias, concediendo a éstas el mismo trato jurídico que a las religiones de mayor tradición histórica en el país (neutralidad abierta hacia todas las religiones, Toleranzslösung ${ }^{9}$ ), con respeto por supuesto a la historia y a la tradición» ${ }^{10}$, entre estos últimos se situaría, por ejemplo, Böckenförde ${ }^{11}$.

Esta resolución se encuadra en la defensa de esta última y presenta varias novedades. La primera, se refiere al modelo de neutralidad, una vez definido este principio constitucional como de neutralidad abierta, el segundo paso sera su utilización innovadora en la ponderación de los derecho fundamentales en juego que como veremos, son los de la igualdad de trato y paridad de las religiones en un contexto social de un creciente pluralismo religioso, el principio de no discriminación por religión, la igualdad de acceso al funcionariado, la no discriminación de las mujeres, el derecho de libertad religiosa de los padres y de los alumnos, así como el mandato constitucional educativo de la escuela y el principio de la paz escolar.

En relación con el primer tema, el BVerfG se posiciona y define cuál es el modelo de laicidad constitucional alemán. Este modelo en realidad estaba bien definido, tanto en la jurisprudencia del BVerfG, como en la doctrina. En suma, ni laicidad negativa o laicismo a la francesa, ni tampoco confesionalidad de Estado (o privilegio

de la Universidad de Deusto, Vol. 63, n. ${ }^{\circ}$ 1, pp. 267-286. Sobre el modelo de integración intercultural que propongo, en contraste con una nueva asimilación, véase ELÓSEGUI, M. (2013). El concepto jurisprudencial de acomodamiento razonable. El Tribunal Supremo de Canadá y el Tribunal Europeo de Derechos Humanos ante la gestión de la diversidad cultural y religiosa en el espacio público. Pamplona, Thomson Reuters-Aranzadi.

7 El Prof. Dr. F. Kirchhof intervino en la vista oral, representando al Estado federado de BadenWürttemberg (Oficina de Enseñanza Secundaria de Stuttgart). Véase BVerfGE 108, 282, IV y II, 6, a: «En la vista oral, el representante de la oficina de Enseñanza Secundaria de Stuttgart, el Profesor Dr. F. Kirchhof, ha afirmado que el deber del Estado de neutralidad ideológico-religiosa debe desarrollarse en adelante de forma más estricta en el ámbito de la escuela, vista a la luz de los cambios sociales».

8 Términos utilizados por BAER, S y WRASE, M. (2005). «Staatliche Neutralität und Toleranz in der "christlich-abendländischen wertewelt" ", DÖV, p. 243. Citados también por BEAUCAMP, G y BEAUCAMP, J. (2015). «In dubio pro libertate», Die Öffentliche Verwaltung, März, pp. 174-183. Aquí p. 177. No porque compartan esta visión, simplemente es para caracterizarla con un término.

9 Idem.

${ }^{10}$ ELÓSEGUI, M. (2015). «La argumentación jurídica del Tribunal Constitucional alemán sobre el uso del velo. Un análisis desde la teoría de la ponderación de Alexy», Libro homenaje al profesor Andrés Ollero, Madrid, Editorial Congreso de los Diputados.

${ }^{11}$ En esta línea podríamos situar la tesis de BÖCKENFÖRDE, E.W. (2007). Der säkularisierte Staat: sein Charakter, seine Rechtfertigung und seine Probleme im 21. Jabrbundert, München, Carl Friedrich von Siemens Stiftung, 41 pp. También MAHRENHOLZ, E.G. (2004). «Ein Kopftuch, aber ach, kein Kopftuch nur, wie faß ich Dich, unendliche Kultur», en BRENNER, M., HUBERT, P.M. y MÖSTL, M. Der Staat des Grundgesetzes - Kontinuität und Wandel. Festschrift für Peter Badura zum siebzigsten Geburtstag, Tübingen, Mohr Siebeck, pp. 749-762. 
de la religión cristiana, aunque con respeto por supuesto a la tradición, y a la religión mayoritaria), y definición de una laicidad abierta que incluye en el espacio público a las religiones minoritarias como la musulmana, por su mayor número entre las minoritarias, todo ello dentro de un respeto a las tradiciones religiosas cristianas alemanas. En este modelo de neutralidad abierta, se hace espacio a los creyentes de otras religiones, sin necesidad de que deba de desaparecer la religión cristiana. Visibilizar otras, sin que desaparezca la mayoritaria. A su vez, todo ello sin que la vía para el respeto consista en la imposición de un espacio público arreligioso o incluso que bajo capa de separación entre lo privado y lo público termine siendo beligerante con el fenómeno religioso, incluido contra los propios cristianos ${ }^{12}$.

Algunos académicos se preguntan si ha habido alguna diferencia en el contexto social entre 2003 (fallada por el segundo senado del BVerfG) ${ }^{13}$ y 2015 (decidida por el primer senado) que hayan inclinado a este último, a diferencia del caso Ludin, a iniciar una toma de posición más favorable hacia una neutralidad abierta que incluya la manifestación de las diversas religiones en el espacio público ${ }^{14}$. Según mi análisis, la razón no radica en que haya habido una diferencia en el número de inmigrantes musulmanes en Alemania en estos últimos años. Los números son muy elevados desde los años 80, incrementado en 1990 con la acogida de 300.000 bosnios, año en el que se registro el mayor número de recepción refugiados, coincidiendo con el actual. A mi juicio, la visibilidad de la presencia de musulmanes se ha producido con una segunda y tercera generación que tienen la nacionalidad alemana, propiciada por los cambios legislativos de 2000 en el Código Civil, que por tanto están accediendo al funcionariado porque han realizado estudios universitarios, a diferencia de sus madres y abuelas, y empiezan a ocupar puestos más visibles, como profesoras, abogadas y juezas. A su vez se percibe otro nuevo fenómeno antropológico y sociológico ${ }^{15}$. Mientras que la primera generación,

12 Este equilibrio no va a resultar fácil en la argumentación de la sentencia, lo que ha causado preocupación lógica en la doctrina. Véase LADEUR, K.H. (2015).«Das islamische Kopftuch in der christlichen Gemeinschaftsschule», JZ, pp. 633-637, quien teme que aunque de momento la interpretación del BVerfG no está en la línea del laicismo francés, se termine orientando la enseñanza en la escuela pública a una especie de religión civil, sin espacio para las creencias religiosas, cfr., pp. 636637. Peligro que también critican duramente con razones de peso KLEIN, E. (2016).«Religionsfreiheit und öffentliche-Schulen», RdJB, 1, pp. 13-29. HEINIG, H.M. (2015).«Ein neues Kapitel in einer unendlichen Gechichte? Verfassungsrechtliche, prozessrechtliche und religions-politische Anmerkungen zum Koptuchbeschluss des Bundesverfassungsgerichts vom 27. Januar 2015», RdJB, 2, pp. 217-232.

13 BVerfGE 108, 282, 4 de septiembre de 2003. Hay traducción al español, realizada por Patricia Cabana en ÁLAEZ CORRAL B. y ÁLVAREZ ÁLVAREZ, L. (2008). Las decisiones básicas del Tribunal Constitucional Federal alemán en las encrucijadas del cambio de milenio, Madrid, Boletín Oficial del Estado y Centro de Estudios Políticos y Constitucionales, pp. 983-1039.

14 VALERO, M.J. (2015). «Neutralidad ideológico-religiosa del Estado y derecho de libertad religiosa en la escuela pública alemana. Reflexiones a propósito de la sentencia del Tribunal constitucional alemán de 27 de enero de 2015», Revista General de Derecho Canónico y Eclesiástico del Estado, n. ${ }^{\circ} 38$, pp. 1-35. Aquí p. 34.

15 POLLACK, D. MÜLLER, O. ROSTA G. y DIETER, A. (2016). Integration und Religion aus der Sicht von Tïrkeistämmigen in Deutschland, Repräsentative Erhebung von TNS Emnid im Auftrag des 
especialmente de mujeres turcas, continúo con sus costumbres de origen, la siguiente generación quiso asimilarse a las costumbres del país de acogida, muchas jóvenes lucharon por emanciparse de su cultura turco-musulmana asimilándose a la cultura alemana, pero en la actualidad hay una tercera generación que quiere ser ambas cosas a la vez alemana y turca, o alemana y musulmana. A ello se une que ahora poseen la nacionalidad alemana y pueden participar en el proceso político ${ }^{16}$.

Frente al tópico de que estas nuevas generaciones, especialmente de mujeres, siguen sometidas al patriarcado paterno ${ }^{17}$, las biografías personales de las demandantes en las sentencias alemanas presentadas ante el Tribunal Constitucional desmienten esos estereotipos. Las recurrentes son mujeres con formación universitaria, en cuyas propias familias otras hermanas no usan, por ejemplo, el velo. Más bien, se observa que ante el intento de asimilacionismo a la cultura del país de acogida por parte de un sector de la sociedad alemana, ellas reivindican sus identidades mixtas, sus raíces culturales de origen y entre otros elementos la religión islámica. Además, quizá haya podido influir al hecho de su visibilidad el hecho de que ahora poseen la nacionalidad alemana y pueden acceder al funcionariado. Con el cambio en los criterios del acceso a la nacionalidad en el año 2000, que admite que los nacidos en Alemania, de padres extranjeros, si uno de los dos lleva ocho años viviendo en Alemania, puede adquirir automáticamente la nacionalidad alemana por ius soli ${ }^{18}$. Esto hizo que en los años inmediatos hubiera un número elevado de naturalizaciones.

Desde 2013, año en el que publiqué mi artículo sobre los efectos del caso Ludin ${ }^{19}$ en las mujeres musulmanas y hasta 2017 el contexto alemán sobre este tema, que es la punta de un iceberg, añade más elementos sociales que explican el devenir jurídico. Con anterioridad, desde la década de 1990 a 2010 hubo profesoras que usaron el velo sin ningún problema ${ }^{20}$. De hecho la prohibición después de 2004 se realizó sólo en ocho Länder y en los otros ocho restantes se sigue permitiendo.

Excellenzclusters «Religion und Politik» der Universität Münster, 13.6.2016, 22 pp. http://www.unimuenster.de

16 BECHTEL, W. (2017). «The State of Racial Justice in Germany», en ELÓSEGUI, M. y HERMIDA, C. (eds.), Racial Justice, Policies and Courts' Legal Reasoning in Europe, Switzerland, Springer, pp. 157-166.

17 POLLACK, D. o.c., p. 9. Por ejemplo, esta tercera generación posee una mentalidad sobre el rol de la mujer muy semejante a sus coétaneas alemanas. Si un el $57 \%$ de las turco-alemanas piensan que el hecho de que la madre trabaje afecta negativamente al cuidado de un hijo, el $46 \%$ de las jóvenes alemanas de origen piensan eso mismo.

${ }_{18}$ Bürgergesetzlichebuch (BGB). Eintragung des Erwerbs der Staatsangehörigkeit nach Satz 1 zu erlassen. $\S 10,(1)$. Aufenthalsgesetz, Gesetz über den Aufenthalt, die Erwerbstätigkeit und die Integraton von Ausländern in Bundesgebiet (Ley sobre el permiso de residencia), 2005, y la Zuwanderungsgesetz (Ley de Inmigración).

${ }_{19}$ ELÓSEGUI, M. «La argumentación jurídica del tribunal constitucional alemán sobre el uso del velo. Un análisis desde la teoría de la ponderación de Alexy», o.c., passim.

${ }^{20}$ MAHRENHOLZ, E.G.«Ein Kopftuch, aber ach, kein Kopftuch nur, wie faß ich Dich, unendliche Kultur «, o.c., p. 757. Aporta el dato de que en el Land de Renania del Norte Westfalia había más de 15 profesoras musulmanas que usaban el velo en el colegio, remitiendo como fuente a SCHWARZER, A. (2003). Der Spiegel 26, 25 de mayo de 2003, p. 92. 
Entre los casos permitidos y otros que rozan la ilegalidad es difícil tener datos precisos, pero según el micro-censo oficial de la Administración del gobierno, se calcula que en el año 2015 había 246.000 turco-alemanes con ambas nacionalidades, también 228.000 rusos (de estos algunos descendían de alemanes y se les permitió la doble nacionalidad) y 220.000 polacos $^{21}$. Pero curiosamente, lo que suscita más debate social es el caso de los turcos, de los que siempre se pone en tela de juicio su lealtad a Alemania y en el que se introduce nuevamente la cuestión de la compatibilidad entre ser musulmán y respetar la democracia occidental. Para Alemania las relaciones con Turquía, por sus tres millones de ciudadanos de origen turco, son siempre mucho más cruciales que para otros países de la UE. La situación de la política de Erdogan en estos momentos repercute en el recelo de los ciudadanos alemanes hacia sus propios conciudadanos turcos. También el Tribunal Constitucional ha tenido que pronunciarse en marzo de 2017 ante un recurso que ha denegado por la aparición del primer ministro turco haciendo campaña a favor de la reforma constitucional en Turquía ${ }^{22}$. Si una palabra refleja la situación es la de complejidad. La sociedad alemana por su pluralidad y diversidad, por la situación geopolítica es compleja. Por tanto, la respuesta constitucional y jurídica sobre el tratamiento de sus ciudadanos alemanes de religión musulmana debe ser también especialmente matizada y ponderada ${ }^{23}$.

\section{LA PONDERACIÓN EN LA DECISIÓN DEL BVERFG DE 2015 SOBRE EL USO DEL VELO POR MAESTRAS}

Además del tema sustantivo, estas sentencias constituyen un buen campo de prueba sobre la racionalidad en la argumentación, así como la vertiente de la jurisprudencia entendida como un arte prudencial, en el que combinar la lógica de los principios con la valoración por parte del juez de los hechos concretos y de las cir-

${ }^{21}$ Fuente: Statistisches Bundesamt, 2015.

${ }^{22}$ Fuente, página web del Tribunal Constitucional Federal alemán. Constitutional Complaint Against Public Appearance of Turkish Prime Minister in Germany Unsuccessful, Press Release No. 16/2017 of 10 March 2017, Order of 08 March 2017, 2 BvR 483/17. La realidad es que han votado en Turquía unos 400.000 turcos que viven en Alemania. La mitad están a favor de la reforma constitucional. Para consultar los resultados de todos los países de Europa, VERGIN, J. (2017). «Türkei-Referendum: (K)eine Frage der Integration?», $D W, 18.04$. 2017, véase http://www.dw.com/de/türkei-referendumkeine-frage-der-integration/a-38464130 (consultado el 7 de junio de 2017). Según se recoge en esa noticia, para el sociólogo Pollack las razones son sentimentales porque sienten que Europa trata mal a Turquía.

${ }^{23}$ De hecho las opiniones en los medios de comunicación ante la resolución de 2015 han estado muy divididas. Véase SACKSOFSKY, U. (2015). «Kopftuch als Gefahr-ein dogmatischer Irrweg», $\mathrm{DVBl}, 13$, p. 801. Unos han considerado que el TC está alejado de la realidad, que peca de ingenuidad, que ignora los conflictos reales en las escuelas: otros, la han calificado de razonable. A algunos pocos les ha parecido insuficiente. Para la misma Sacksofsky es un gran avance en la igualdad de las mujeres musulmanas, pero todavía con limitaciones en su implementación. Ella abogaría por la supresión de esas leyes prohibitivas y por la utilización de los límites a los DF previstos en la LF. 
cunstancias del caso. La ponderación y el principio de proporcionalidad no son una regla matemática sino que exigen la interpretación judicial ${ }^{24}$. Si aplicamos la fórmula del peso de Robert Alexy a la cuestión controvertida ${ }^{25}$, deberíamos pesar en la balanza varios derechos:

Por un lado, según el Derecho alemán nos encontramos con varios derechos fundamentales y algunos principios constitucionales: entre los primeros situaríamos la misión educativa del Estado en las escuelas públicas, además los derechos de los padres a educar a sus hijos según sus convicciones, la libertad religiosa negativa de los alumnos a no recibir influencia religiosa si no lo quieren, y por último, un principio o fin de la escuela que es la paz escolar, en el sentido de evitar todo aquello que cree conflictos de convivencia entre los alumnos y entre éstos y los profesores, o entre estos últimos entre sí. A pesar de que este principio de la paz escolar no tenga rango constitucional es un instrumento o un medio para que el Estado pueda realizar su función educativa $^{26}$, que sí es un mandato constitucional.

Del otro lado de la balanza, se encontraría la libertad religiosa positiva de cualquier ciudadano alemán (art. 4 LF), libertad que sigue vigente en la actuación de los funcionarios del Estado, con limitaciones específicas, además el derecho de libertad religiosa debe interpretarse en el contexto de la neutralidad religiosa del Estado alemán, pero como una neutralidad abierta y amistosa con las religiones y con el ejercicio individual de la libertad religiosa. A este principio, se añade el de la paridad de trato por parte del Estado de todas las religiones, sin que haya una religión oficial del Estado y sin privilegiar una en detrimento de las otras. Otros derechos fundamentales que se sitúan en este lado serían el principio de igualdad y no discriminación, tanto por motivo religioso (art. 4 LF), como de género (art. 3 LF). Además debemos añadir el derecho de igualdad de oportunidades en el acceso Eudeba.

${ }^{24}$ CLÉRICO, L. (2009). El examen de proporcionalidad en el derecho constitucional, Buenos Aires,

25 ALEXY, R. (2016). «Un concepto no positivista de derecho fundamental. Sobre la relación entre teoría de los principios, derechos fundamentales y moral», en ELÓSEGUI ITXASO, M. (Coord.), Los principios y la interpretación judicial de los Derechos Fundamentales. Homenaje a Robert Alexy en su 70 Aniversario, Zaragoza, Fundación Giménez Abad, Alexander von Humboldt Stiftung y Marcial Pons, pp. 27-45. Sobre la fórmula del peso, véase p. 31. La versión en alemán se encuentra en el mismo libro. También ALEXY, R.(2016). «La dimensión real e ideal del Derecho», Prensas Universidad de Zaragoza, Colección Paraninfo Honoris Causa, Zaragoza, pp. 39-50. Versión en Inglés: «The real and the Ideal Dimensión of Law», pp. 51-61. Ambas versiones disponibles en: http://intercultural.unizar.es/MARIA_ ELOSEGUI/NOVEDADES.html

${ }^{26}$ Ver el comentario de U. SACKSOFSKY a esta última sentencia, «Kopftuch als Gefahr-ein dogmatischer Irrweg», o.c., p. 806. Según la autora la paz escolar no es por sí misma un bien constitucional y no puede justificar una prohibición de un Derecho Fundamental por el hecho de que ese ejercicio moleste a otros que no comparten esa creencia. Sacksofsky lleva tiempo insistiendo en este punto de que los derechos de libertad no tienen porqué ceder ante los prejuicios y atribuciones de los demás. Véase SACKSOFSKY, U. (2007). «Religion und Emanzipation- (k)ein Widerspruch?», en KADELBACH, S. y PARHISI, P. (eds.), Die Freibeit der Religion im europäischen Verfassungsrecht, BadenBaden, Nomos, pp. 111-121. 
a la función pública (art. 33 LF), sin discriminación por motivo de religión, raza o sexo, así como el derecho constitucional de elegir profesión, de un modo general (art. 12 de la LF).

El fallo del Tribunal Constitucional en esta decisión de 2015 ha sido que no se puede establecer una ley general prohibiendo el uso del velo a la profesoras en las escuelas públicas alemanas porque sería contrario a la Constitución y que sólo se podría prohibir en los casos concretos en que ello represente un peligro real en unas determinadas circunstancias y no por un peligro meramente abstracto. En esta sentencia se da prioridad al derecho de libertad religiosa individual de las profesoras y se justificaría su restricción sólo en el caso de que se probara un peligro concreto ${ }^{27}$. En este supuesto la libertad individual de manifestar la religión prevalecería ante el principio de la paz escolar tomada en abstracto. De manera que un Land no está legitimado a realizar una ley general prohibiendo el uso de símbolos religiosos de los funcionarios como derecho preventivo ante hipotéticos conflictos.

Por todo ello, parte de la doctrina ha señalado que esta decisión elaborada por el primer senado del BVerfG alemán se separa notablemente de la sentencia del caso Ludin en temas de fondo ${ }^{28}$, pero, otra parte de la doctrina a pesar de sus críticas al procedimiento, consideran que ha habido una continuidad en varios temas de la dogmática constitucional ${ }^{29}$. Ambos senados han estado formados por distintos jueces, con excepción de uno de ellos que precisamente ha emitido un voto particular ${ }^{30}$,

27 Véase WOLFF, A.H. (2015). «Anmerkung», BayVBl, pp. 489-494. Aquí, p. 491.

28 Según VOLKMANN, U. o.c., p. 1084, la dimensión dogmática de esta segunda sentencia es destacable por el cambio de orientación en relación con el mensaje (confuso) que se había enviado al legislador de los Länder en la sentencia del caso Ludin. Son varios los autores que opinan que debería haberse llamado al pleno. Entre ellos PAPIER, H.J. (2015). «Zur Kopftuch-Entscheidung des Bundesverfassungsgerichts», $R d J B$, p. 213. Este último muy crítico con lo que considera una injerencia del poder judicial en la soberanía del poder legislativo elegido democráticamente (véase, pp. 215-216). También comparte la idea de que debería haberse llamado al pleno, SACKSOFSKY, U. «Kopftuch als Gefahr-ein dogmatischer Irrweg», o.c., p. 807. La discusión de fondo es sobre qué aspectos formaban parte de los fundamentos de derecho y cuáles eran obiter dicta. Tonio Klein sustenta también la opinión de que se orientó mal al legislador, sin embargo considera que hay una continuidad entre ambas sentencias. En mi opinión, aunque así fuera en parte, sí que el segundo senado había señalado con claridad que se debía respetar el principio de paridad de las religiones, principio del que el legislador de Renania del Norte Westfalia hizo caso omiso.

${ }^{29}$ Muchos son críticos con la primera sentencia y su ambigüedad. Realmente pretendió dejar en manos del legislador cuestiones en las que éste debe respetar la Constitución y están claramente definidas.

${ }^{30}$ Monica Hermanns y Wilhem Schluckebier. La primera formó parte del tribunal del segundo senado del BVerfG que falló el caso Ludin. Ha participado en esta segunda sentencia en sustitución de Ferdinand Kirchhof, vicepresidente del BVerfG, y que había participado en el dictamen de la Ley de educación de Renania del Norte-Westfalia, cuando todavía no formaba parte del tribunal federal constitucional. KIRCHHOF, F. (2004). Anbörung vor dem Ausschuss für Schule, Jugend und Sport des wadenwürttembergischen Landtags am 12.3.2004, Ausschussprotokoll. Gesentzenwurf der badenwürttembergischen Landesregierung, LT-Drs. 13/2793. 
disintiendo del fallo y reiterando los argumentos del caso Ludin, decidido por el segundo senado del BVerfG. De hecho, los artículos académicos se hacen eco de esta amplia diferencia y siendo que uno de los senados no puede enmendar a otro, discuten sobre si se debería haberse llamado al pleno ${ }^{31}$. De todos modos, ni siquiera los dos votos particulares se han mostrado partidarios de proceder de ese modo ${ }^{32}$.

Para amparar el recurso de las dos demandantes, el TC ha hecho una clara interpretación a favor de una neutralidad abierta y positiva del Estado frente al fenómeno religioso, incluso cara a los funcionarios públicos. El primer Senado da todavía un paso más allá, en relación con las bases sentadas en la sentencia de 2003, que llevaron en esa ocasión a un fallo un tanto desconcertante.

Me parece central señalar desde el inicio, sin espera a las conclusiones del presente artículo, que esta decisión está mejor argumentada y es más coherente en su fallo con las premisas que sienta. Bastantes de las críticas que realicé a la sentencia Ludin por su falta de coherencia argumentativa, por su falta de lógica jurídica, por inferencias que no se seguían de las premisas son claramente superadas por esta nueva decisión, que se ha atrevido a llevar a sus últimas consecuencias el derecho constitucional alemán en varios puntos dogmáticos que ya estaban sentados cuando se pronunció la sentencia Ludin.

Bien es verdad que, además, este senado se ha visto enfrentado con las consecuencias negativas de la sentencia anterior y no ha tenido miedo de anular el inciso 3 del Art. 57.4 de la Ley de Educación de Renania del Norte, ejerciendo su competencia de control de constitucionalidad de las leyes emanadas por los parlamentos de los Länder $^{33}$. Como analizaremos posteriormente, hay pruebas sobradas en los trabajos prelegislativos de que el parlamento no actúo inocentemente, sino a sabiendas de la posible inconstitucionalidad. Las consecuencias legales y jurisprudenciales de este

31 MÖLlERS, C. (2015). «A Tale of two Courts», Verfassungsblog. On matters Constitutional. 14 de marzo de 2015, Disponible en http://Verfassungsblog.de/a-tale-of-two-courts/. (Consultado el 6 de abril de 2017). Ver también, HONG, M. (2015). «Ein Gericht oder Zwei Gerichte. Der Kopftuch-beschluss, das Plenumsverfahren und der Grundsatz "stare decisis" , Der Staat 54, pp. 409-434.

${ }^{32}$ Lo destaca, por ejemplo, KLEIN, T. «Das Koptuch im Klassenzimmer: konkrete, abstrakte, gefülthe Gefahr?», o.c., p. 466.

33 En relación con el extenso debate sobre si esta nueva sentencia revierte o no la doctrina del segundo senado, cabe decir que aceptando que se pronuncia con claridad sobre puntos como la neutralidad del Estado, pero no con novedad, mantiene lo que era doctrina mayoritaria de una neutralidad abierta. A su vez, es cierto que el primer senado cita continuamente la primera sentencia dando a entender que se sitúa en continuidad con ella, sin añadir ni una palabra o ninguna explicación sobre un posible disenso. Sin embargo, esto no me parece negativo porque en realidad el primer senado se pronuncia sobre una situación nueva, sobre una Ley que no existía cuando se emitió el fallo anterior. Con lo cual en este sentido, no existía un precedente. Si bien UwE WOLKMANN es muy crítico con este silencio, o.c., p. 1087. Para una discusión de fondo sobre el tema procesal véase, HONG, H. (2015). «Ein Gericht oder Zwei Gerichte? Der Kopftuch-Beschluss», Der Staat 54, pp. 409-434 y FRANZIUS, C. (2015). «Vom Kopftuch I zum Kopftuch II» Der Staat, 54, pp. 435-352. Si bien Hong es contrario a llamar al pleno por motivos pragmáticos de justicia sustantiva o material, entre otros. De hecho en toda la historia del TC sólo se ha llamado al pleno en cinco ocasiones. 
segundo fallo han sido inmediatas porque ya se está aplicando su doctrina en tribunales inferiores. A modo de muestra, se ha dictado recientemente una sentencia en el Lasdesarbeitsgericht de Berlin-Brandenburgo ${ }^{34}$ que declara inconstitucional el artículo de la Ley de Berlín, que prohibía el uso de símbolos religiosos a funcionarios públicos y personal contratado que trabaja en dichos servicios ${ }^{35}$.

En Bremen el legislador ha solicitado un dictamen para estudiar si su ley es compatible o no con la doctrina de esta nueva sentencia ${ }^{36}$. En la doctrina algunos consideran que ha habido una injerencia en el poder del legislativo ${ }^{37}$, pero a mi juicio también el legislador puede actuar en ocasiones de un modo autoritario y no respetuoso con los Derechos Fundamentales. En opinión de Hong, que comparto, no existe una politización del Tribunal Constituciona alemán, sino una diferencia en cuestiones de aplicación de la ponderación, las diferencias son más bien técnicas, de

${ }^{34}$ LAG Berlin-Brandenburg, 09.02.2017 - 14 Sa 1038/16. Dos Cortes constitucionales de los Länder se habían pronunciado ya sobre la constitucionalidad de sus nuevas leyes de educación. Hesse, Hessischer StGH, Urt. V. 10.12.2007. P.St. 2016- LverG 18, 279 (303). También en Baviera, BayVerfGH, 15.1.2007 (Vf.11-VII-05), NVwZ 2008, 420 (203). De todos modos, la Ley de Educación de Baviera está redactada de tal modo que podría ser considerada conforme a la Constitución, incluso después de esta reciente sentencia. En una sentencia de Osnabrück de este año, VG Osnabrück (Verwaltungsgericht Osnabrück), 18.01.2017, 3. ${ }^{a}$ 24/16, a pesar de la ley del Land de Bremen que prohíbe el uso de símbolos religiosos a todos los funcionarios se ha fallado a favor del recurso de una profesora en prácticas necesarias para alcanzar la titulación, al considerar que éstas son obligatorias y que el Estado tiene el monopolio de las mismas, por lo que no puede impedir que una persona acceda a un título porque sería discriminatorio. Caso diferente es desempeñar un puesto como funcionario o contratado laboral para la Administración, situación que no ostenta una estudiante en prácticas. Aunque la recurrente no ve reconocido el derecho a la indemnización que reclamaba.

35 LAG Berlin-Bradenburg, 09.02.2017 - 14 Sa 1038/16. Esta última casa la sentencia de la instancia judicial inferior, Arbeitsgerichts (ArbG) Berlin, v. 14.04.2016, Az. 58 Ca 13376/15. El Landesarbeitsgericht en una sentencia de 40 páginas, aplica la decisión del BVerfG y conforme a ella reconoce la discriminación laboral de la reclamante y declara que la Ley de neutralidad del Land de Berlín, (Gesetz zu Artikel 29 der Verfassung von Berlin vom 27.01.2005, GVB1. 2005, 92), debe interpretarse a la luz de la nueva decisión del BVerfG, 27.01.2015 (1 BvR 471/10, 1 BvR 1181/10. Además se obliga al Land a pagar una indemnización de un salario de tres meses, una suma de 8.680 euros, que corresponden a los transcurridos desde la denegación del puesto de trabajo debido a que la solicitante dijo que quería usar el velo y probado que si no hubiera sido por ese hecho le hubieran otorgado el puesto de funcionaria porque tenía un buen cv. El primer juez había opinado que la decisión del BVerfG era sobre una Ley del Land de RNW y que por tanto su contenido no afectaba a la Ley de Berlín porque ésta prohibía todos los símbolos religiosos y no tenía cláusula de privilegio. No consideraba que hubiera discriminación laboral. Una crítica de la sentencia de la primera instancia, LÖWENBRÜCK, L.S. (2016). «Wie neutral sind Berlins Schulen?», Heinrich Böll Stiftung, Migrationspolitisches Portal, 22 de abril de 2016. Disponible en: https://heimatkunde.boell.de/2016/04/22/ wie-neutral-sind-berlins-schulen (consultado 3 de abril de 2017).

36 Véase SACKSOFSKY, U. «Kopftuch als Gefahr-ein dogmatischer Irrweg», o.c., p. 808, nota 67. http://www.radiobremen.de/nachrichten/gesellschaft/kopftuch-an-schulen100.html.

37 KLEIN, E. (2016). «Religionsfreiheit und öffentliche Schulen», RdJB, 1, pp. 13-29. HEINIG, H.M. «Ein neues Kapitel in einer unendlichen Gechichte?», o.c., passim. 
argumentación jurídica, de ponderación y de aplicación del principio de constitucionalidad, y no ideológicas ${ }^{38}$.

Es claramente una sentencia que pone los medios para una inclusión social y acceso a la administración de las ciudadanas alemanas de religión musulmana, con origen en la inmigración, y que además aboga por la inclusión y no expulsión del mercado de trabajo de esas mujeres ${ }^{39}$. Todo ello con una correcta técnica jurídica, aunque queden algunos últimos detalles que precisarían de una mayor claridad. Entre ellos, la concreción de cuándo nos hallamos ante un peligro concreto, qué procedimientos deberían seguirse para tomar medidas, y quién está legitimado, la duda de si el concepto de peligro es adecuado en el contexto educativo y si no sería más adecuado la resolución de conflictos cotidianos en los propios centros escolares y con la inspección educativa, y no por reglamentos, y en suma si estas leyes prohibitivas, en el resto de los Länder, que han estado encaminadas tan sólo a prohibir el velo en profesoras deberían de dejar de existir. De hecho junto a los ocho Länder que introdujeron leyes prohibitivas, hay otros ocho que no lo han hecho ${ }^{40}$, algunos con gran número de población de religión musulmana.

Al margen de estas consideraciones, en la doctrina hay serias críticas en relación con la coherencia entre la sentencia Ludin y la resolución de 2015, así como sobre la falta de homogeneidad en los criterios de ponderación utilizados por el BVerfG a lo largo de su jurisprudencia en temas relacionados con el derecho de libertad religiosa. Especialmente en lo referente al criterio de la prevalencia de la libertad positiva y de la libertad negativa del ejercicio del derecho de libertad religiosa y a la prioridad de uno u otro, que se ha aplicado de diferente modo, especialmente en la sentencia relacionada con la prohición del crucifijo en las aulas de las escuelas del Land de Baviera. También existen problemas serios sobre los criterios de interpretación del significado de los símbolos religiosos, la opinión del que los porta, el significado que posee para los observadores, o el criterio de interpretación del Estado y de los tribunales.

La novedad en esta resolución es que en el caso de autos conduce a declarar la inconstitucionalidad del inciso $3 .^{\circ}$ del art. 57.4 en la Ley educativa del Land de Renania del Norte-Westfalia, en la que se otorga un tratamiento preferente a favor

38 HONG, M. «Ein Gericht oder Zwei Gerichte? Der Kopftuch-Beschluss», o.c., pp. 409-434. También a favor de la continuidad, KLEIN, T. o.c., p. 466. Muy crítico considerando que el Tribunal Constitucional está politizado y ha invadido las competencias del parlamento autonómico, no respetando la división de poderes, VOLKMANN, U. o.c., p. 1091.

39 SACKSOFSKY, U. o.c., p. 808. Se muestra claramente a favor de la resolución, de la que afirma que va en la dirección correcta, a diferencia de la anterior sentencia del caso Ludin, en relación con la dogmática de la libertad religiosa y de los derechos religiosos de las minorías. La sentencia se inclina hacia un reconocimiento individualizado de las religiones, no sólo del reconocimiento colectivo de las confesiones, que era el más habitual en la dogmática constitucional alemana. El ver en el pañuelo un peligro le parece un camino erróneo. Considera la nueva sentencia un paso adelante, aunque lo deseable para ella es que desaparecieran estas prohibiciones.

40 Branderburgo, Hamburgo, Mecklenburgo, Vorpormmenrn, Rheinland Falz, Nieder-Sachsen, Sachsen-Anhalt, Schleswig-Holstein. 
del uso de símbolos o vestimentas propias de la religión cristiana o de la cultura occidental. Por otro lado, el Tribunal declara como discriminatorio el hecho de identificar a la persona que usa velo como una persona antidemócrata, que no respeta el orden constitucional alemán. Además otra novedad constitucional consiste también en que es el primer caso en el que el BverfG se pronuncia sobre la constitucionalidad de las leyes de educación que se legislaron en ocho Länder después del caso Ludin, prohibiendo el uso del velo en las profesoras (en dos Länder extensibles a todos los funcionarios). En la sentencia Ludin el tribunal había dejado en manos de los Länder la posibilidad de hacer leyes que legislaran sobre el punto del uso de símbolos religiosos en la escuela por parte del profesorado cuando hubiera un peligro abstracto de lesionar los DF de terceros. La reacción fue que ocho Länder introdujeron esta legislación ${ }^{41}$. Cinco de ellos permitiendo el uso de símbolos cristianos en detrimento de otras religiones. Como ya he comentado en otros artículos, la crítica en el ámbito académico de este tratamiento discriminatorio ha sido cuantiosa por considerar estas leyes anticonstitucionales, pero hasta ahora no había dado tiempo a que los recursos planteados de inmediato hubieran agotado las instancias judiciales inferiores y hubieran podido plantear un recurso de amparo ante el BVerfG.

En esta nueva resolución se realiza un mejor ejercicio de ponderación y se otorga un mayor peso y prioridad a los derechos fundamentales de libertad religiosa de los funcionarios. Como contraste, la sentencia Ludin amparó el recurso de amparo de esa profesora, pero a su vez hizo de abogado del diablo, poniendo en las manos del Land argumentos para que pudiera justificar una ley prohibitiva del uso del velo basada en un posible peligro abstracto para la paz escolar. La sentencia de 2003 cae en contradicciones, porque si de una parte sienta las bases de que no se puede declarar como inidónea para un cargo publico a una persona por el hecho de que use velo, luego deja abierta la duda de que dicha persona pueda ser defensora de los valores constitucionales alemanes o su conducta constituya en sí un peligro para la paz escolar. Otra de las contradicciones es que no logra aportar pruebas empíricas científicas de que en la práctica en Alemania se puede decir que a los escolares les choque ver a una profesora con velo, ya que los académicos consultados afirman que no hay ninguna prueba empírica de que haya habido una influencia negativa $\mathrm{o}$ presión en los escolares por ello ${ }^{42}$ (posible adoctrinamiento). A pesar de ello y de

${ }^{41}$ Baden-Würtember (09.04.2004). En la ley sobre la escuela. Schulgesetz. Baviera (23.11.2004). Artikel 59 Gesetz über das Erziehungs-und Unterrichtswesen. Berlin (27.01.2005). Gesetz zu Artikel 29 der Verfassung von Berlin. Bremen (09.07.2005). §59b Schulgesetz. Hessen (18.10.2004). Niedersachen (29.04.2004). Nordhrein-Westfalen (13.06.2006). §57 Schulgesetz. Saarland (Sarre) (23.06.2004). § 1 Schlornungsgesetz.

42 De hecho en 2013 en una estancia de investigación en Kiel puede entrevistar a Thomas Bliesener, Catedrático de Psicología evolutiva de la Universidad de Kiel, al que el BVerfG le solicitó un dictamen, a raíz del caso Ludin, sobre estudios científicos que demostraran la influencia negativa del uso del velo de una profesora en los alumnos. Me facilitó el dictamen y me confirmó que no hay ninguna prueba de una influencia negativa. 
un modo incoherente, en la sentencia Ludin el BverfG considera que ante la posibilidad de un peligro abstracto el legislador del Land pueda hacer leyes preventivas prohibitivas.

Como luego resaltaremos, es indudable que los alumnos están bajo una situación especial de sujeción ante la posición de autoridad de un profesor y que debe ejercerse por parte del centro escolar, de las administraciones y de los padres una especial vigilancia para evitar el influjo negativo de los profesores. Lógicamente teniendo en cuenta cada contexto habrá que vigilar para que las alumnas musulmanas que no quieren usar velo no se sientan presionadas por el hecho de que una de sus profesoras lo use. Para ello, habrá que extremar las precauciones en los centros escolares, pero ello no justificará a juicio de la resolución de 2015 una ley prohibitiva preventiva. Argumento que comparto, compatible con los límites especiales que deben aplicarse a la conducta de los profesores en su tarea de docencia.

Un buen ejercicio de ponderación exige hacer un análisis del caso concreto, utilizando pruebas ${ }^{43}$. En esta segunda sentencia se deja claro que los hechos probados del caso evidencian que no ha existido por parte de los padres, ni de los alumnos ninguna queja por la actuación de las dos demandantes en sus tareas, una como trabajadora social y la otra como docente. Ambas trabajan en ambientes interculturales, con alumnos de todas las religiones. Como critiqué entonces en relación con el caso Ludin, «Si llevar símbolos religiosos por parte de funcionarios está amparado en el art.4.2 de la LF, la existencia de una ley prohibitiva basada en el peligro potencial no convierte la decisión del legislador en legal, porque se sentaría una ley prohibitiva injusta y discriminatoria, basada sólo en prejuicios previos no demostrados empíricamente». La nueva resolución de 2015 confirma esta tesis. Otra de mis críticas fue que el segundo senado del BVerfG hacía una inferencia indebida al explicar el modelo de neutralidad presente en la Constitución alemana porque la doctrina mayoritaria y la jurisprudencia anterior del propio tribunal habían dejado claro que haciendo una interpretación sistemática de la LF el modelo alemán era un modelo de separación, pero con cooperación entre el Estado y las religiones. Por tanto, la posibilidad que dejaba abierta el TC en 2003 de que era posible interpretar la neutralidad de la LF de dos modos: uno abierto hacia la religiones y otro cerrado al modo del laicismo francés, no se ajusta a la realidad del derecho constitucional alemán e introducía un elemento extraño en el mismo, ya que el modelo de la neutralidad distanciada de las religiones no es el modelo defen-

43 FRINGS, D. (2012). «La libertad de culto de los empleados de la administración pública conforme al art. 33, párrafo 3 de la Ley Fundamental con respecto a la neutralidad del Estado»/ «Der Religionsfreiheit der öffentlichen bediensteten nach Art. 33 Abs. GG im Verhältnis zur Neutralität des Staates», en ELÓSEGUI, M. (Coord.) La neutralidad del Estado y el papel de la religión en la esfera pública en Alemania, o.c., pp. 173-197 (versión en español), pp. 351-384 (versión en alemán). Según la autora: «El centrarse en un peligro abstracto evita la comprobación concreta de un enfrentamiento con los derechos fundamentales y abandona el requisito del derecho constitucional de alcanzar una compensación lo más conciliadora posible por la vía de la concordancia práctica» (pp. 192-193). 
dido por la Ley Fundamental de Bonn. De hecho los nuevos comentarios de una gran número de académicos alemanes a raíz de la última resolución recalcan que si en el futuro el legislador alemán decidiera otra cosa, se necesitaría realizar un cambio constitucional ${ }^{44}$.

En esta nueva sentencia se hace un ejercicio de aplicación del principio de proporcionalidad más adecuado, si bien se realiza de un modo implícito y sin señalar estrictamente los pasos habituales previstos entre los teóricos de la ponderación, pasos que intentaremos destacar por nuestra parte en la conclusión.

\section{LOS HECHOS Y LA LEY DE LA ESCUELA DE RENANIA DEL NORTE WESTFALIA}

El fallo se produce ante dos recursos de amparo planteados por dos alemanas de religión musulmana de origen turco que trabajan en la escuela pública como personal contratado. A raíz de la reforma de la Ley escolar en 2006, después del caso Ludin, en el mencionado Land se reformó la Ley de la Escuela prohibiendo usar símbolos religiosos que pudieran alterar la paz escolar y que además fuera susceptible de interpretarse que la persona que los usa no respeta los valores constitucionales. Como punto de partida de nuestro análisis comenzaremos por recoger la literalidad del art. 57, del texto normativo en pugna, la Ley escolar (Landesschuldgesetz) de Renania del Norte Westfalia (a partir de aquí citada como LSchuldG RNW), ya que la Sentencia del Tribunal Constitucional examinará punto por punto la conformidad o no de este articulado en relación con la Constitución alemana. Según dicho artículo:

$\left(1 .^{\circ}\right)$ Las profesoras y los profesores no deben mostrar en la escuela ninguna manifestación política, religiosa, ideológica u otras expresiones externas similares, las

${ }^{44}$ KLEIN, T. o.c., p. 470. Afirma que no ha sido una decisión política, sino conforme al derecho constitucional. La neutralidad amistosa o de acuerdos de cooperación con las religiones es patente en todo el derecho eclesiástico del Estado alemán. Véase STARCK, C. (2012). «La libertad religiosa en Alemania como libertad positiva y negativa»/ «Religionsfreiheit in Deutschland als positive und negative Freiheit», en ELÓSEGUI. M (Coordinadora), La neutralidad del Estado y el papel de la religión en la esfera pública en Alemania, o.c., pp. 63-74 (versión en castellano), pp. 291-302 (versión alemana). También ENNUSCHAT, J. «La cooperación entre el Estado y la Iglesia en escuelas y universidades», en ELÓSEGUI, M. (coordinadora), La neutralidad del Estado y el papel de la religión en la esfera pública en Alemania, o.c., pp. 89-100. Versión alemana «Die Kooperation von Staat und Kirche im Bereich von Schule und Hochschule», pp. 303-312. Por otro lado el trato paritario de las religiones no significa un trato equivalente, ya que es lógico respetar las tradiciones y la religión de la mayoría, aunque se vayan introduciendo una atención también a la religión islámica (cuatro millones de ciudadanos), suní y aleví, a los ortodoxos (un millón y medio) etc. Atención al pluralismo y a la diversidad no es equivalente a eclecticismo. Es el peligro también de una interculturalidad mal entendida que termine en una multiculturalidad ecléctica, intuida entre otros por PAPIER, H.J. (2015). «Zur Kopftuch-Entscheidung des Bundesverfassungsgerichts «, RdjB, pp. 213-232, y LADEUR, K.H. (2015). «Das islamische Kopftuch in der christlichen Gemeinschaftsschule», JZ, pp. 633-637. 
cuales sean susceptibles de alterar o de poner en peligro la neutralidad del Estado federado frente a las alumnas y los alumnos así como frente a los padres o la paz política, religiosa o ideológica en la escuela.

$\left(2 .^{\circ}\right)$ En especial, se prohíbe cualquier conducta externa que pueda causar la impresión entre las alumnas, los alumnos o entre los padres, de que una profesora o un profesor actúe en contra de la dignidad humana, la igualdad de derechos según el artículo 3 de la Ley Fundamental, el derecho fundamental de libertad o el régimen constitucional de libertad y democracia.

$\left(3 .^{\circ}\right)$ El ejercicio de la misión educativa, de acuerdo con los artículos 7 y 12, apartado 6 de la Constitución del Estado federado de Renania del Norte-Westfalia y de la correspondiente representación de valores educativos y culturales cristianos y occidentales y de sus tradiciones no entra en contradicción con las normas de comportamiento establecidas en la el apartado 1. .

$\left(4 .^{\circ}\right)$ El deber de neutralidad contemplada en la frase $1 .^{a}$, no se aplicará a las clases de religión, ni a las escuelas confesionales o ideológicas» ${ }^{45}$.

Según el artículo 58 SchulG NW, esa disposición es igualmente aplicable al personal no docente, pero que desarrrolla labores pedagógicas, como los trabajadores sociales. Igualmente según el párrafo 6 del $§ 57$ SchulG NW: «La actitud (punto de vista) de una profesora o de un profesor debe asumir las disposiciones del párrafo 4 a lo largo del tiempo de servicio, como una característica personal de su idoneidad. Además rige también para el traslado de una profesora o profesor desde otra Administración a un centro escolar del Land de Renania del Norte-Westfalia. Para las y los profesores en prácticas y en formación pueden contemplarse excepciones si su solicitud se hizo antes de la regulación, en la medida en que el ejercicio de sus derechos fundamentales que necesariamente se requiere no entren en conflicto con el interés público superior de protección de la neutralidad del Estado y de la paz escolar».

La demandante del procedimiento $1 \mathrm{BvR}$ 471/10 nació en Alemania y desde los 17 años decidió llevar el velo a diferencia de sus tres hermanas. Ejerce como trabajadora social en una escuela pública de Düsseldorf, en el Land de Renania del Norte-Westfalia desde 1997. Su trabajo esencialmente es de mediadora para la integración y resolución de conflictos escolares entre los alumnos provenientes de diversas culturas $^{46}$. Había trabajado durante diez años usando el velo sin problemas hasta la

45 Ley de Educación de Renania del Norte-Westfalia, SchulG RNW, en la versión del 13 de junio de 2006, § 57 párr. 4 de la Ley de Educación de Renania del Norte-Westfalia de 15 de febrero de 2005 GV.NRW. S. 102), modificada por la Primera Ley de Educación para el Land de RNW, el 13 de junio de 2006 (GV.NRW.S. 270). La traducción es nuestra.

${ }^{46}$ Cfr., BVerfG, Decisión del 27.1.2015, 1 BvR 471/10, 1 BvR 1181/10, § 8. 
reforma de la Ley de Educación en 2006, cuyo contenido acabamos de citar. En ese momento, conforme a lo solicitado por el Consejo escolar de que no se usara el velo en el centro escolar, esta trabajadora sustituyó el velo por el uso de una boina, y un jersey de cuello alto, que le tapaba el pelo. En una entrevista con el director, aunque no respondió de forma directa a la pregunta de porque usaba ahora esta prenda, sí afirmó que había usado el velo por motivos religiosos. Esta razón es importante para el BVerfG porque se va a apoyar en este hecho para otorgar protección a su conducta como parte del derecho constitucional de libertad religiosa del art. 4 de la LF. La Junta escolar le dirigió una advertencia para que tampoco usara esa prenda con la amenaza de expulsión en caso de que persistiera en su conducta por infracción del $\$ 57$ párr. 4 de la SchulG de $\mathrm{RNW}^{47}$. La afectada recurrió a la vía judicial laboral, primero al tribunal laboral (Arbeitsgericht) exigiendo la supresión de esa advertencia en su expediente laboral.

Con ello comenzó una larga carrera de instancias judiciales hasta agotar todos los procedimientos posibles, el Tribunal de trabajo del Land, (Landesarbeitsgericht) y el Tribunal Federal de Trabajo (Bundesarbeitsgericht) llegando a interponer un recurso de amparo ante el Tribunal Constitucional alemán ${ }^{48}$. El Juzgado de lo social desestimó su recurso argumentando que, según lo dispuesto en la mencionada Ley, sólo por el hecho de llevar ese prenda se infería que lo hacía por motivos religiosos islámicos. En ese caso se asumía que no defendía el principio de igualdad constitucional entre mujeres y hombres, y que no respetaba por tanto los valores constitucionales ${ }^{49}$. Manifestar externamente una creencia religiosa por parte de un profesor constituía potencialmente un peligro abstracto para la neutralidad y la paz del centro escolar, entendiendo que la norma del Land no sólo prohibía manifestaciones externas que constituyesen un riesgo cierto para los bienes jurídicos protegidos. Además, al legislador del Land, democráticamente elegido ${ }^{50}$, le correspondía legislar qué tipo de neutralidad considera más adecuada para la escuela, si una neutralidad estricta distanciada de las religiones o una neutralidad más abierta que diera cabida a la diversidad religiosa creciente en la escuela, como un posible medio para la práctica de la tolerancia.

En realidad, estos últimos argumentos no hacen más que repetir lo que había sentado el BVerfG (en su segunda cámara) en la sentencia Ludin. Si bien a nuestro juicio, la SchulG del Land de RNW, no responde a ninguno de esos dos tipos de

47 Cfr., BVerfG, Decisión del 27.1.2015, 1 BvR 471/10, 1 BvR 1181/10, § 9

${ }^{48}$ Las sentencias judiciales emitidas fueron: De la primera demandante (trabajadora social) del asunto 1 BvR 471/10: ArbG Düsseldorf, 29. 06. 2007 - 12 Ca 175/07, LAG Düsseldorf, 10.04.2008 - 5 Sa 1836/1807, BAG, 20.08.2009 - 2 AZR 499/08, BVerfG, 26.02.2014- 1 BvR 471/10,

49 Cfr., BVerfG, Decisión del 27.1.2015, 1 BvR 471/10, 1 BvR 1181/10, § 12

50 BOROWSKI, M. (2014). «Subjekte der Verfassungsinterpretation», en ISENSEE, J. und KIRCHHOF, P. Handbuch des Staatsrechts der Bundesrepublik Deutschland, Band XII, Normativität und Schutz der Verfassung, Dritte, völlig neuearbeitete und erweiterte Auflage, MÜLLER, C.F. pp. 761-782. Se explica la función del legislador como intérprete de la Constitución en pp. 776-779. 
neutralidad, sino a una especie de confesionalidad cristiana encubierta, como en breve analizaremos. Por otro lado, según esta primera instancia la legislación es conforme a la LF.

En el segundo caso, la demandante empezó a trabajar como maestra contratada laboral del Land de Renania del Norte Westfalia en 2001. Ejercía su docencia en varias escuelas públicas impartiendo turco como segunda lengua como asignatura optativa para niños cuyos padres eran de origen turco. Siempre había usado velo. A partir de 2006 la consejería del Land le exige que deje de utilizar el velo. Ella desatiende esa petición y se le cursa una advertencia laboral con amenaza de una sanción de despido en caso de incumplimiento. De hecho, se le despide el 30 de junio de 2007. Sus demandas son denegadas por el Juzgado laboral, así como por el Tribunal Federal de Trabajo, que considera que la demandante ha violado las condiciones del contrato de trabajo y que el despido está justificado por incumplimiento de su deber ${ }^{51}$. El hecho de que sus alumnos sean estudiantes musulmanes no cambia nada en relación con la obligación de neutralidad de los profesores de la escuela pública ${ }^{52}$. El Tribunal Federal de Trabajo, que para entonces ya había fallado el caso anterior, mantiene sus tesis de la conformidad de la Ley de la escuela de RNW con la Constitución alemana, con el art. 9 del CEDH y con el art. 7 del AGG (Allgemeines Gleichbehandlungs Gesetz) ${ }^{53}$, tampoco admite la diferencia de trato, a pesar de que una religiosa con hábito de clases en la Escuela en Paderborn en una escuela para discapacitados visuales ${ }^{54}$. El Tribunal afirma haber realizado una ponderación de intereses justificando la decisión de despido ${ }^{55}$. Como consecuencia, la maestra una vez agotadas todas las instancias laborales pertinentes interpone un recurso de amparo ante el Tribunal Constitucional.

Un argumento importante que esgrime la demandante y que el BverfG hará suyo, es que los fallos de las instancias anteriores son inconstitucionales porque carecen de una ponderación concreta (konkrete Abwägung) en el contexto de ese caso individual (Einzelfallprïfung). No existen pruebas de que la demandante haya lesionado los derechos de terceros. Según el derecho alemán, el principio de concordancia práctica exige una ponderación del caso concreto, cuando exista colisión entre $\mathrm{DF}^{56}$. Es decir, habría que probar que en ese caso esa profesora ha hecho manifestaciones contrarias a

51 De la segunda demandante (profesora de turco) del asunto 1 BvR 1181-1110: ArbG Herne (Tribunal de Trabajo), 07.03.2007- 4 Ca 3415/6, ArbG Herne (Tribunal de Trabajo), 21.02.2008-6 Ca 649/07, LAG Hamm, 16.10.2008 -11 Sa 280/08, LAG Hamm, 16.10.2008, 11 Sa 572/08 BAG, 10.12. 2009 - 2 AZR 55/09, BVerfG, Decisión 1 BvR 1181/10.

52 Cfr., BVerfG, Decisión del 27.1.2015, 1 BvR 471/10, 1 BvR 1181/10, § 33.

53 Cfr., BVerfG, Decisión del 27.1.2015, 1 BvR 471/10, 1 BvR 1181/10, § 34.

${ }^{54}$ Cfr., BVerfG, Decisión del 27.1.2015, 1 BvR 471/10, 1 BvR 1181/10, § 35.

55 Cfr., BVerfG, Decisión del 27.1.2015, 1 BvR 471/10, 1 BvR 1181/10, § 37.

56 Cuando existe colisión entre Derechos Fundamentales se debe buscar una solución «basada en la concordancia práctica de tales derechos fundamentales y valores constitucionales, debiendo procurar la eficacia de cada uno de ellos en la concreta situación fáctica generada», HEINIG, H. y MORLOCK, M. (2003). «Von Schafen und Kopftüchern-Das Grundrecht auf Religionsfreiheit in Deutschland vor den Herausforderungen religiöser Pluralisierung», Juristen Zeitung, p. 782. 
la Constitución o ha intentado adoctrinar. De hecho, como quedará reflejado en la nueva sentencia de revisión, posterior al fallo del BVerfG en el recurso de amparo, la Administración del Land no pudo presentar nada al respecto. En el caso de la primera demandante se derogan (se casan) las sentencias del Bundesarbeitsgericht de 20 de agosto de 2008 y la sentencia del Landesarbeitsgericht de Düsseldorf y el juicio del Tribunal de Trabajo de Düsseldorf (Arbeitsgericht). El asunto se remite nuevamente al Landesarbeitsgericht de Düsseldorf. El resultado será que posteriormente con fecha de 1 de junio de $2015^{57}$ este tribunal obliga al Land de RNW a pagar las costas de los juicios a la demandante y a eliminar de su expediente la advertencia sancionadora que le compelía a no usar la boina.

En el caso de la segunda demandante también se anulan las sentencias del Landesarbeitsgericht de Hamm, las sentencias del tribunal de trabajo de Herne de 21 de febrero de 2008 y la de 7 de marzo de 2007 por haber violado el derecho fundamental de libertad religiosa del art. 4. Párrafos 1 y 2 de la Constitución alemana. Igualmente se derogan las sentencias del Tribunal Federal alemán y del Landesarbeitsgericht de Hamm y se remite el caso nuevamente a este último tribunal ${ }^{58}$.

\section{LOS ARGUMENTOS DEL BVERFG EN LOS FUNDAMENTOS DE DERECHO}

El orden de los temas que se van a seguir en la resolución para realizar un ejercicio de ponderación son los siguientes: en un lado de la balanza están los derechos de los funcionarios, que incluye el derecho de libertad religiosa (art. $4 \mathrm{LF}$ ) y el derecho de acceso en igualdad al funcionariado (Art. 33 LF) y a no ser discriminado por razón de sexo (art. 3 LF). Además, se discute en qué consiste la neutralidad exigida a los funcionarios. En el otro lado de la balanza se sitúan la libertad religiosa negativa de los niños, el derecho de los padres de educar a sus hijos según sus creencias. Además todos estos derechos hay que compaginarlos con la misión educativa de la escuela que corresponde al Estado, encuadrada en el respeto a la neutralidad ideológico-religiosa positiva de la Constitución Alemana. A continuación nos centramos, siguiendo la decisión, en el control de constitucionalidad de la norma del Land sobre educación, art. 54 de la SchulG RNW, analizando detalladamente cada uno de los incisos el 1, el 2 , el 3 y el 4 . Se considerara el tercero de ellos como discriminatorio para el acceso en igualdad a la función pública y será anulado. En los incisos 1 y 2 se debe hacer una interpretación restrictiva para que el texto sea conforme a la LF.

Para todo ello, el Tribunal hará un análisis de ciertos conceptos jurídicos indeterminados, así como del contenido sustantivo de los derechos fundamentales implicados en el caso, en el marco del principio de tolerancia, que ha sido elaborado con

${ }^{57}$ LAG Düsseldorf, 01.06.2015, 5 Sa 3017/15

${ }^{58}$ Se decide con nueva sentencia Landesarbeitsgerichts Hamm, 15.04.2015 - 2 Sa 1325/14. 
mucha profundidad en la dogmática constitucional alemana. Este mandato de tolerancia dirigido a los legisladores en una democracia como la alemana implica que el legislador debe de adoptar soluciones jurídicas que impliquen un compromiso razonable para con todos los ciudadanos ${ }^{59}$, también con las minorías, remitiendo a la sentencia Ludin ${ }^{60}$.

El BVerfG subrayó ya en esta última que la neutralidad del Estado en las escuelas públicas puede significar una neutralidad abierta inclusiva que permita todas las religiones, aceptando el aumento de una diversidad de religiones en la escuela y usando este hecho como una vía para practicar la mutua tolerancia y una contribución para lograr la integración o podría interpretarse como una neutralidad estricta no religiosa. Si se entiende del primer modo con apertura, el Estado podría tolerar que un profesor utilice símbolos religiosos en la escuela sin que ello sea equiparable al hecho de que el propio Estado ordenara usar símbolos religiosos en el propio colegio, por ejemplo crucifijos en las aulas. Es decir, con otras palabras, el Estado podría permitir que los profesores manifiesten individualmente su religión, sin necesidad de que se atribuya al Estado las religiones de sus profesores. En ese caso, compatible con lo dicho, se trata de estudiar si hay otros derechos constitucionales en conflicto, como el interés de los padres, los derechos de los niños a la libertad de religión, y el posible impacto de las manifestaciones religiosas de los profesores en los alumnos, así como el peligro de interferencia con la paz del colegio, en el caso de que perjudique al clima necesario para ejercer la docencia en el centro escolar.

La nueva sentencia es contundente. El mandato educativo del Estado a la educación y su deber de neutralidad ideológico-religioso debe ser compatible con la libertad religiosa positiva del profesorado. Afirma que esta neutralidad no debe entenderse en términos de una estricta separación entre la Iglesia y el Estado, sino como un proceso abierto y transversal para todos los credos, con un trato igualmente amistoso (amable) para todos ellos ${ }^{61}$.

Las principales conclusiones del Tribunal Constitucional, que atañen a ambas demandantes, cabe sintetizarlas del siguiente modo: una prohibición general del uso del velo en profesoras en la enseñanza pública a través de una ley general es contraria al derecho de libertad de religión previsto en el art. 4 de la Constitución alemana. En sentido positivo, el art. 4 párrafo 1 y 2 de la LF garantiza a los maestros de la escuela pública poder usar un velo islámico cuando se entiende que esta prenda forma parte de la obligación religiosa ${ }^{62}$.

En nuestro análisis seguiremos el orden que el Tribunal utiliza, consistente en comenzar por los derechos que amparan a las recurrentes (V), desglosando su contenido y sus límites, empezando por el de la libertad religiosa de los funcionarios, y siguiendo por los derechos de terceros (VI), de los alumnos y de los padres (VII),

59 Cfr., BVerfG, 27.01.2015, 1 BvR 471/ 101 BvR 1181/10, § 98 a).

${ }^{60}$ Cfr., BVerfGE 108, $282<302$ f $>$.

${ }^{61}$ BVerfG, 27.01.2015, 1 BvR 471/ 101 BvR 1181/10. Resumen inicial (3 ) (a).

${ }^{6}$ Cfr., BVerfG, 27.01.2015, 1 BvR 471/ 101 BvR 1181/10. Resumen inicial $\S 1$. 
para finalizar con el examen de la constitucionalidad del art. 57.4 de la SchulG de RNW (VIII), concluyendo con una valoración personal sobre la ponderación realizada por el BVerfG (IX).

\section{LOS DERECHOS DE LAS RECURRENTES}

\section{V.1. El derecho de libertad religiosa de los funcionarios en las escuelas públicas y el uso de prendas religiosas en ese espacio}

El BVerfG realiza una cadena de razonamientos, en los que insistirá en la obligación para determinados creyentes de cubrirse la cabeza con un velo en público, como parte de su identidad cultural y/o religiosa ${ }^{63}$. En síntesis, el BVerfG concluirá que los educadores en la enseñanza pública, en cuanto que empleados del servicio público, no pierden su derecho de libertad religiosa y deben poder seguir las reglas de su fe en relación con la vestimenta, como por ejemplo usar el velo islámico si hay razones plausibles ${ }^{64}$. Los derechos fundamentales de las demandantes no deben ponerse en duda por el hecho de que trabajen para el Estado porque éste debe de respetar también los DF de sus empleados, tanto de los que ostenten la condición de ser funcionarios de carrera, como de los que tienen una relación contractual laboral $^{65}$. En cuanto al contenido del derecho de libertad de creencias del art. 3 LF no sólo protege la libertad interior sino también la libertad externa de manifestar (expresar) la fe. Incluye no sólo los actos de culto y el ejercicio y observancia de las costumbres religiosas, sino también el derecho de los individuos a que todo su comportamiento sea coherente con las enseñanzas de su fe y vivir conforme a sus convicciones $^{66}$.

${ }^{63}$ KLEIN, T. o.c., p. 466. Sobre la importancia para la identidad personal. WOLFF, H.A. o.c., p. 490. SACHS, M. (2014). GG7, sobre los límites de los funcionarios en el ejercicio de su función. También sobre el uso de prendas religiosas en la escuela POTTMEYER, M. (2011). Religiöse Kleidung in der öffentlichen Schule, Tübingen, Mohr Siebeck.

64 BverfGE 108, $282<297 \mathrm{f}>$.

65 BVerfGE 128, $226<245>$.

66 BVerfGE 128, $226<245>$, citada en BVerfG, 27.01.2015, 1 BvR 471/ 101 BvR 1181/10\$ 84 y $§ 85$. TRAUB, T. (2015). «Abstrakte und konkrete Gefahren religiöser Symbole in öffentlichen Schulen», NJW, N. ${ }^{\circ} 19$, pp. 1338-1340. Este autor destaca el énfasis del BVerfG en un accionamiento activo del ejercicio de libertad religiosa, con un nuevo acento (p. 1340). U. SACKSOFSKY, o.c., p. 803. Afirma que con esta interpretación se amplía el ámbito de protección otorgado al art. 4 de la LF. En el voto particular de esta decisión y también en el caso Ludin se insiste más bien en las restricciones de los derechos de los funcionarios por su especial situación de sujeción. No comparte el voto particular, KLEIN, T. o.c., p, 467. Crítico con la interpretación excesivamente subjetiva e ironizándola, BRODER, H.M. «Würden Verfassungsrichter auch Nudister Schützen?», http: //www. welt.de/debate/Henryk-m-broder/article138471498/Wuerden-Verfassungsrichter-auch-Nudistenschuetzen.html., citado por SACKSOFKY, U. o.c., p. 803, nota a pie número 3. A mi juicio, no se debe trivializar cuando existen peticiones sobre acomodamientos o ajustes razonables por motivos 
En relación con la interpretación de cuáles sean las obligaciones religiosas merecedoras de protección constitucional, se deben de tener en cuenta varios criterios: las creencias que el individuo manifiesta tener y que son importantes para él (elemento subjetivo $)^{67}$. El TC pone de relieve los problemas de interpretación que subyacen a raíz del uso de un pañuelo como el velo islámico porque así como la cruz cristiana tiene un significado claramente religioso, en el caso del velo islámico depende tanto de la interpretación subjetiva de quien lo usa, como de la interpretación del observador. Eso queda más patente en el uso que hace la primera demandante de una boina, ya que en sí no es una prenda religiosa ${ }^{68}$. Pero ambas recurrentes invocan un significado religioso de las prendas que usan y las consideran obligatorias para respetar sus convicciones.

El BVerfG en esta sentencia se esfuerza también por insistir en el significado religioso del uso del velo, al margen de los motivos diversos que puedan llevar a su utilización. Recalca que para muchas mujeres musulmanas es una obligación religiosa. Con ello persigue darle protección constitucional bajo el derecho de libertad religiosa, ya que una cuestión cultural no tendría las mismas garantías constitucionales $^{69}$. En cuanto al control del elemento subjetivo y objetivo, el BVerfG hace también un control mínimo de la objetividad del precepto religioso remitiéndose al Corán y aceptando el testimonio de las dos demandantes y los motivos por los que ellas lo usan, aunque no sea una razón monolítica entre las mujeres musulmanas. Por tanto deben ponderarse todas esas perspectivas equilibradamente y no dar sólo mayor peso al elemento subjetivo, si bien es crucial darle gran relevancia.

religiosos. En general, las causas suelen ser serias y la jurisprudencia muestra que las razones suelen ser de peso. Además los recursos judiciales suponen costes económicos, psicológicos, de tiempo, largos, ante diversas instancias, y en muchos casos el recurso se produce ante despidos laborales, que implican graves perjuicios económicos para los demandantes. Además, los jueces hacen un test sobre la seriedad de lo alegado.

${ }^{67}$ Hay una línea de pensamiento entre filósofos y sociólogos que apunta en esta dirección de la mayor importancia que debe dársele a la religión como un fenómeno individual. En Alemania por ejemplo el sociólogo Pollack de Münster. Crítico porque puede ser una vía que sea aprovechada a favor del fundamentalismo islámico, LADEUR, K.H. (2016). «Burkaverbot in der Schule - Art. 7 Abs. 1 GG als Grundlage für eine "Religionspolitik" des Staates'». Zum Beschluss des VG Osnabrück v. 22.8.2016 -AZ.: IB 81/16», RdJB, pp. 379-386. Ladeur argumenta que dar excesivo peso al criterio de interpretación subjetivo no es aceptable, comentando esta sentencia de Osnabrück en la que se le prohibió a una alumna usar el niqab en la escuela (velo que sólo dejaba ver los ojos). La alumna alegaba que el Corán lo exigía. El tribunal administrativo en el que la alumna presentó un recurso contra el centro escolar ha confirmado la legalidad de la prohibición, basándose en la necesidad de ver la cara de los alumnos para la comunicación en la escuela.

68 BVerfG, 27.01.2015, 1 BvR 471/ 101 BvR 1181/10, § 93 y $\$ 94$.

69 SACKSOFSKY, U. o.c., p. 803, comparte esta misma opinión. 


\section{2. El acceso en igualdad a la función pública y la discriminación de las mujeres musulmanas}

El BVerfG analiza con profundidad los efectos discriminatorios contra las mujeres musulmanas de una legislación que prohíba el uso del velo, cuestión que las instancias judiciales anteriores habían omitido. El efecto de esta prohibición sobre el uso del velo es que las mujeres musulmanas están siendo excluidas de la profesión de maestras, lo cual es una discriminación contraria al art. 33 de acceso al funcionariado en igualdad y sin discriminación por razón de religión, o de sexo. También se produce una discriminación de la igualdad de las mujeres contemplada en el art. 3 de la $\mathrm{LF}^{70}$. En mi opinión, aunque las instancias anteriores no hayan querido aceptar una doble discriminación de estas maestras por el factor religioso y por razón del género, alegando que la redacción de la norma se refiere tanto a los hombres como a las mujeres, esa afirmación no se sostiene jurídicamente porque precisamente la discriminación indirecta según la definición de la Directiva de la UE sobre igualdad en el acceso al empleo se basa en los efectos concretos discriminatorios de la ley en su aplicación práctica ${ }^{71}$. Es evidente que en Alemania no ha habido ningún despido de hombres maestros musulmanes, ni de ningún otro por motivos religiosos. Sí ha habido por ejemplo una prohibición a un maestro de llevar una pegatina en el colegio durante el cumplimiento de sus obligaciones escolares con un lema contra las centrales nucleares: «Atomkraft? Nein Danke!» ${ }^{72}$. El Tribunal Federal Administrativo consideró que el profesor vulneraba la prohibición de no mostrar una conducta política durante el ejercicio de su trabajo.

Volviendo a nuestro caso, es más, la discriminación laboral contra las mujeres musulmanas prohibiéndoles usar el velo se extiende a otras profesiones como la de las prácticas durante la carrera de derecho, el desempeño de la defensa de clientes por abogadas en los tribunales y en la judicatura. Hay numerosa controversia por ejemplo en el Land de Baviera sobre este punto ${ }^{73}$. Se puede discutir sobre la conve-

70 BVerfG, 27.01.2015, 1 BvR 471/ 101 BvR 1181/10, §96.

71 Directiva 2002/73/CE del Parlamento Europeo y del Consejo, relativa al principio de igualdad de trato entre mujeres y hombres en lo que se refiere al acceso al empleo, a la formación y a la promoción profesionales, y a las condiciones de trabajo. Directiva 2000/43/CE, de 25.01.1990, relativa a la aplicación del principio de igualdad de trato de las personas independientemente de su origen racial o étnico.

72 BVerwGE 84, 292. BVerwG 2 C 50.88. 25.01.1990. Tribunal Federal Administrativo. Ver por ejemplo LADEUR, K.H. «Das islamische Kopftuch in der christlichen Gemeinschafschule», o.c., p. 635. También comentan esta sentencia WICHMANN, M. y LANGER, K.U. (2007). Öffentliches Dienstrecht, 6 Auflage, Deutscher Gemeindeverlag, Kohlhammer, p. 137 sobre los profesores de colegios.

73 DPA/ACR/LTO-REDAKTION, (2016). «Richterverbände offen für gesetzliche Regelung. Kopftuchverbot für Richterinnen im Amt?», Legal Tribune Online, 08. 08. 2016. www.lto.de. (consultado 24 de abril de 2017). El Tribunal Administrativo de Augsburgo (Land de Baviera) en junio de 2016 ha fallado que es inadmisible una prohibición del velo para las abogadas en prácticas establecida 
niencia o no de que los jueces como representantes del Estado (lo que no afectaría a los abogados que no son funcionarios, sino que es una profesión liberal ${ }^{74}$, aunque en Alemania se les equipara a los funcionarios públicos) porten símbolos religiosos, pero lo que no tiene sentido en mi opinión es que se exija neutralidad absoluta a estas profesionales en unas salas de juzgado que están presididas por el crucifijo en algunos Länder como Baviera. Este último caso, que los edificios de una institución pública asuman un signo confesional (aunque obedezca a la tradición y sería partidaria de respetarlo en las escuelas cuando los usuarios así lo desean), es más incoherente con la neutralidad estatal que el uso de símbolos por parte de los funciona$\operatorname{rios}^{75}$. En cualquier caso, la lógica debería ser que el que permite lo más, permite lo menos, por lo que debería permitirse ese símbolo religioso en esos Länder que están dando la batalla contra el velo.

En cualquier caso, el BverfG considera que las consecuencias de esa prohibición causan una mayor lesión a las mujeres musulmanas en el acceso a la enseñanza que en el resto de ciudadanos, luego en la ponderación hay que darle el peso debido a esta interferencia en sus derechos de igualdad porque son afectados más gravemente que otras personas a las que se les permite además emplear otros símbolos religiosos $^{76}$.

El TC está de acuerdo, lógicamente, con el hecho de que el legislador debe de proteger los DF de terceros (los derechos de los alumnos y de los padres, la neutralidad de la escuela, la paz escolar), lo que ocurre es que el legislador de RNW ha realizado una prohibición preventiva desde el inicio para evitar posibles colisiones a base de eliminar la práctica de un derecho fundamental. Como se observa en la lectura de los trabajos preparatorios ${ }^{77}$, lo cual es cuestionable ${ }^{78}$, e incluso sin que se hayan dado ningún tipo de conflicto.

por el Landesjustizministerium, porque esta orden no tiene un rango de ley y sólo por ley se puede establecer restricciones en los derechos constitucionales.

${ }^{74}$ De esta opinión han sido los dos siguientes tribunales. Sobre la ley de neutralidad de Berlín y su repercusión en los abogados, véase Bundesverwaltungsgericht, Urteil 26.06.2008. (Az. 2 C 22.07). La obligación de neutralidad obliga sólo a los funcionarios y no a los profesionales liberales. Kammergericht Berlin, Urteil 9. 010. 2012 (Az. (3) 121 Ss 166/12 (120712). Falla que una mujer con velo puede formar parte del jurado en la sala del juzgado (dado que en Alemania existe el jurado escabinado). También el Verwaltungsgericht Düsseldorf, 8. 11. 2013 (Az. 26 K 5907/12) falla que el uso del pañuelo no puede ser un obstáculo para el acceso a la pasantía. Véase, GRUNERT, M. (2014). «Mit Kopftuch im Referendariat», Legal Tribune Online, 24. 02. 2014.

75 Sobre esta relación triangular del principio de neutralidad, en relación por un lado del Estado con sus funcionarios, por otro del Estado con los usuarios y, por último, de los usuarios con los funcionarios, véase la clarificadora monografía de VAN OOIJEN, H.M. (2012). Religious symbols in public functions: unvelling state neutrality: a comparative analysis of Dutch, English and French justification for limiting the freedom of public officials to display religious symbols, Cambridge, Antwerp, Portland (Oregon), Intersentia. Concretamente el capítulo 4, pp. 79-115.

76 BVerfG, 27.01.2015, 1 BvR 471/ 101 BvR 1181/10, § 96.

77 Ver LTDrucks 14/569, página 7 y ss. BVerfG, 27.01.2015, 1 BvR 471/ 101 BvR 1181/10, § 99 b)

78 BVerfG, 27.01.2015, 1 BvR 471/ 101 BvR 1181/10, § 100 c) 


\section{EL OTRO LADO DE LA BALANZA: LOS DERECHOS DE TERCEROS. EXAMEN DE LOS LÍMITES A LOS DERECHOS FUNDAMENTALES EN EL CASO PRESENTADO. PELIGRO CONCRETO VERSUS PELIGRO ABSTRACTO}

En el otro lado de la balanza se sitúan la libertad religiosa negativa de los alumnos, de los padres, la misión educativa de la escuela desde la neutralidad ideológica y el fin legítimo de la paz escolar. Para ello el juzgador debe ponderar los intereses en juego usando el principio de proporcionalidad. Estos derechos juegan también como límites al ejercicio del derecho de libertad religiosa de los profesores. Pero no se puede priorizar estos cuatro derechos fundamentales ante un peligro abstracto de tal manera que justifique el desplazamiento del ejercicio de un derecho fundamental de una obligación religiosa imperativa. En este caso el BVerfG hace un examen de los límites inmanentes del derecho de libertad religiosa siguiendo la tradición de la dogmática constitucional alemana ${ }^{79}$.

Comienza el TC un estudio ponderativo diferente al que la segunda cámara realizó en el caso Ludin, dando más peso en la balanza al derecho de libertad religiosa de los profesores, siempre que no haya indicios de que estos no respeten los derechos de terceros, es decir, de los alumnos, de los padres o de los otros profesores. La falta de respeto se concretaría en que enseñaran algo contrario a los contenidos escolares previstos o los valores constitucionales, por su especial deber de fidelidad a la constitución. Si bien lo que se nombra de un modo explícito es la prohibición de adoctrinar (o de evangelizar) $^{80}$.

Como señala Valero, el BVerfG examina las «Posibles límitaciones legales de las libertades reconocidas en el art. 4.1. y 4.2. de la LF para que éstas sean proporcionados y conformes a la Constitución. En definitiva, el Tribunal pretende responder a las preguntas de en qué circunstancias y bajo qué condiciones puede el legislador limitar válidamente el derecho de profesores y pedagogos a expresar mediante su apariencia externa su ideología o sus creencias en el espacio educativo público aconfesional $\gg^{81}$. En el derecho alemán los límites al ejercicio de los derechos son los clásicos reconocidos en la norma y en la doctrina: los derechos de los demás, el orden constitucional (verfassungsmäßige Ordnung) y la moral (Sittengesetz) ${ }^{82}$, lo que incluye el orden público (en este caso la paz escolar), la seguridad y valores sociales de rango constitucional. La tensión entre estos DF y bienes constitucionales debe ser resuelta desde el mandato de tolerancia.

79 SACKSOFSKY, U. o.c., p. 809.

80 BVerfG, 27.01.2015, 1 BvR 471/ 101 BvR 1181/10, § 103

81 VALERO, M.J. o.c., pp. 23-24.

82 HILLGRUBER, C. (1999). «Der deutsche Kulturstaat und der muslimische Kulturimport. Die Antwort des Grundgestezes auf eine religiöse Herausforderung», Juristen Zeitung, p. 543. STARCK, C.

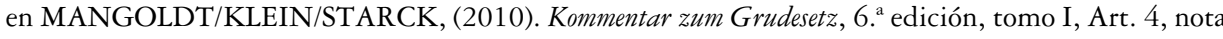
marginal 42 y ss. 
Examinados estos límites, el TC concluirá que la prohibición general a través de una ley del Land de todas las expresiones religiosas basadas en la apariencia externa sólo por el hecho de que exista un peligro abstracto de alterar la paz o la neutralidad del Estado en una escuela pública no confesional es inadecuado, especialmente si impide el ejercicio de un derecho fundamental obligatorio. En todo caso, cabe establecer una prohibición cuando haya un peligro suficientemente concreto de los intereses protegidos y debe hacerse con una interpretación restrictiva ${ }^{83}$. Parte de la doctrina ha criticado que se utilice el concepto de peligro en el ámbito de las leyes educativas, ya que lo consideran un concepto más propio del derecho administrativo o de la función policial del Estado ${ }^{84}$.

Para evaluar la situación actual son los legisladores los que tienen un margen de interpretación (prerrogativa de evaluación). Se debe mantener una proporción adecuada según el peso y la importancia del derecho fundamental de los docentes, así como una ponderación general entre el peso de la intervención (de la interferencia o injerencia en los DF, que va a ser calificada de grave), y el peso de los otros derechos DF, y sus límites razonables ${ }^{85}$.

\section{VI.1. La libertad religiosa negativa de los alumnos y el límite de probibición de adoctrinamiento por parte de los profesores}

En relación con el derecho de los padres a la educación, la libertad religiosa negativa de los alumnos y la misión educativa del Estado, el posible peligro que existe es el de que los maestros vayan más allá de sus derechos y ejerzan una influencia adoctrinadora o evangelizadora en sus alumnos, debido también a que están en una edad más influenciable y que los profesores ocupan un lugar de autoridad y que los niños deben permanecer en el recinto educativo. Todo ello se discutió ya en la sentencia del caso Ludin y en otra jurisprudencia alemana ${ }^{86}$. Pero la conclusión es que ninguno de esos derechos constitucionalmente consagrados tienen por si mismos tal peso que justifiquen una prohibición de usar una prenda religiosa que es parte del derecho de libertad religiosa de los profesores basándose en un peligro abstracto.

Muy importante resulta el análisis de en qué consiste la libertad negativa de los estudiantes. No deben ser obligados por la escuela a participar en la asignatura

83 BVerfG, 27.01.2015, 1 BvR 471/ 101 BvR 1181/10, § 101. d)

${ }^{84}$ Entre ellos, WOLFF, H.A. o.c., p. 492. VOLKMANN, U. o.c., p. 1085. Para éste último hablar de peligro concreto es muy inseguro porque resulta un concepto muy indefinido. Tampoco le parece bien que haya que esperar a recibir quejas de padres o alumnos. Wolkmann se pregunta si basta un par de padres o debe ser un grupo grande (p. 1086). PAPIER, H.J. o.c., p. 215, es crítico por la ambigüedad de exigir sólo la actuación de la administración a nivel del centro ante el peligro concreto. Tanto Volkmann como Papier coinciden en afirmar que los centros escolares públicos en Alemania no son unos lugares idílicos, sino que en ellos se reflejan los conflictos presentes en la actual sociedad.

85 BVerfG, 27.01.2015, 1 BvR 471/ 101 BvR 1181/10, § 102 aa)

86 Caso Ludin, BVerfGE 108, 282, <303>. 
de religión (que se oferta en Alemania también en las escuelas estatales como asignatura optativa, protestantismo, catolicismo, religión judía, también clases de religión ortodoxa y se han empezado clases de religión islámica suni y alevíi) ${ }^{87}$, ni a participar en actos de culto ${ }^{88}$. Existe ya una larga jurisprudencia sobre este tema, prohibición del rezo antes de las clases o con determinadas restricciones para que nadie de otras confesiones se sienta herido, o del crucifijo en la escuela (muy controvertido en Baviera $)^{89}$. Pero eso no implica estar libre de ver que los demás muestren sus propias creencias. Como señala el profesor Starck, no se puede pretender vivir en una sociedad libre de religión, como libre de humo porque eso impediría a los demás el ejercicio de un derecho fundamental ${ }^{90}$. El BverfG admite que el uso de una vestimenta externa es un ejercicio de libertad positiva de la religión. En el caso de profesores de religiones minoritarias, eso se equilibra con la presencia de profesores de otras religiones, lo que es un reflejo de una sociedad plural y religio$\mathrm{sa}^{91}$, con la que los alumnos se enfrentan en su vida cotidiana en Alemania ${ }^{92}$. En este punto, lo que ha criticado duramente parte de la doctrina es la incoherencia entre la diversa jurisprudencia del BVerfG en estas materias, lo que no es objeto del presente artículo. Es forzado reconocer que en la sentencia del crucifijo en las aulas del Land de Baviera se priorizó la libertad negativa de un estudiante frente a

${ }^{87}$ BVerfG, 27.01.2015, 1 BvR 471/ 101 BvR 1181/10, § 104. ENNUSCHAT, J. «La cooperación entre el Estado y la Iglesia en escuelas y universidades», o.c., p. 94. UNGERN-STENBERG, A. VON. (2016). «Islamischer Religionsunterricht und islamische Theologie- die Suche nach Verfassungskonformen Lösungen», $R d J B, 1$, pp. 30-42. En p. 36. describe una clase de religión para todos, llevada por la Iglesia evangelista, dirigida a los alumnos de todas las confesiones y organizada por las religiones con más presencia en el Land. El gobierno de Hamburgo ha realizado acuerdos con las comunidades islámicas DITIB, Schura, VIKZ, la comunidad alevita de Alemania, la comunidad evangélica y la comunidad judía de Hamburgo. Esta clase de «religión para todos» además de subrayar el diálogo y la tolerancia entre las religiones, plantea al mismo tiempo la enseñanza de la religión en una línea más secular en un mundo multireligioso. La consecuencia es que, en esta propuesta, se dejaría de impartir la asignatura de cada religión con sus contenidos confesionales y propios. Sobre la legislación de Hamburgo véase, BAUER, J. (2014). «Die Weiterentwicklung des Hamburger Religionsunterrichts in der Diskussion zwischen Verfassungsrecht und Schulpädagogik», ZevKR, 59, pp. 227-256. DEMEL, M. (2013). «Die Verträge Hamburgs mit islamischen Verbänden und der Alevitischen Gemeinde», KuR, p. 93 y ss.

${ }_{88}$ BVerfGE 52, 233. Sobre la admisibilidad de la oración interconfensional en la escuela.

89 BVerfGE 93, 1. Prohibido por el BVerfG, pero aplicado de manera que se ha dejado en las escuelas y puede quitarse a demanda si alguien se siente molestado por ello.

90 STARCK, C. o.c., p. 67. «Recurriendo al componente negativo de la libertad religiosa tampoco es posible reclamar un entorno sin religión sin el sonido de las campanas, la llamada del muecín, símbolos religiosos, etc. El Tribunal Constitucional alemán sentenció en 2003 que del art. 4 de la LF no se deduce ningún derecho de librarse de manifestaciones de fe ajenas, acts de culto y símbolos religiosos». Veáse BVerfGE 108, 282, 302.

91 BVerfG, 27.01.2015, 1 BvR 471/ 101 BvR 1181/10, § 105.

92 En la doctrina, hay unos que están en contra de esto y otros a favor. Para unos eso perturba el clima para poder enseñar en un clima tranquilo, para otros es una educación más conforme a las necesidades de la realidad social con la que se ven confrontados los alumnos. También hay división entre los jueces. Están en contra de introducir el pluralismo en la escuela los votos particulares de la última decisión, así como los tres votos disidentes de la sentencia Ludin. 
la libertad positiva de todos los demás que quieren que él aula esté presidida por el crucifijo. Sobre todo nuevamente a raíz de esta resolución de 2015 algunos académicos intuyen el peligro de que se vaya marginando la religión cristiana o postergándola ante otras nuevas. Otros critican que los fallos judiciales no han sido homogéneos, pero hay que entender también que están condicionados por las circunstancias del cada concreto y eso puede llevar a fallos distintos, justificados siempre que se respeten unos criterios dogmáticos homogéneos en la interpretación de la Constitución. De acuerdo con la interpretación del TC tanto en esta sentencia como en Ludin no es la misma la neutralidad exigida a las instituciones educativas (el edificio o las aulas), que la exigida a los empleados, así como a los usuarios, si bien en algunas cuestiones las líneas de separación son muy sutiles. Una propuesta de neutralidad abierta, no es ni laicista, ni confesional, si bien la aconfesionalidad no debe llevar tampoco a marginar a la religión o creencias mayoritarias.

A continuación el BVerfG vuelve a tratar el derecho de libertad religiosa de los funcionarios, que ya lo ha indicado en el lado de la balanza a favor del profesor, pero ahora señala sus límites cara a los alumnos y la obligación de no adoctrinar como respeto a la libertad negativa del derecho de religión de los alumnos y límite a la libertad positiva religiosa de los profesores.

Aquí se da un paso más en la lógica de la argumentación. Cabría pensar que en el caso de los profesores por su especial situación de sujeción al Estado como funcionarios, este derecho quedara anulado. Sin embargo el TC, tanto en esta sentencia como en reiteradas ocasiones, ya ha señalado que debe distinguirse entre la neutralidad exigida al empleado y la neutralidad exigida al Estado, y que ambas no se identifican, sino que se mueven en dos niveles distintos ${ }^{93}$. No hay por qué imputar la religión de los profesores a la escuela misma, siempre que éstos respeten la religión de los alumnos. Aun teniendo en cuenta la situación especial del alumno en la clase que no puede escaparse de la visión de la vestimenta del profesor. En el caso de que esta vestimenta se deba al ejercicio del derecho de libertad religiosa, también los alumnos deben practicar un respeto al margen de libertad de las convicciones religiosas de los profesores (que no se pueden dejar de puertas afuera). Habrá que distinguir entre qué conductas están amparadas por los DF y cuáles no. Para Bökenförde ya no se puede continuar hoy en día con una mentalidad sobre la identificación del funcionario con el Estado propia del año $1949^{94}$. También Sachs señala que la situación de especial sujeción al poder administrativo no anula los derechos del funcionario y no los restringe a su vida privada ${ }^{95}$. Entre ellas está la

93 TRAUB, T. o.c., p. 1339. Subraya que la dogmática constitucional ha diferenciado entre el uso individual de signos religiosos realizado por los funcionarios frente a un mandato legal de Estado de que las aulas deban estar presididas por el crucifjo ( $\$ 13$ Bay-Volksschulordnung).

94 BÖCKENFÖRDE, E.W. (2001). «Kopftuch streit auf der richtigen weg?», NJW, pp. 723-715. También WOLFF, H.A. o.c., p. 490, se inclina por el reconocimiento del funcionario como titular de derechos individuales dentro del ejercicio de su función pública.

95 SACHS, M. (2004). «Wiederbelebung des besonderen Gewaltverhältniss?», NWVBL, p. 209. 
vestimenta externa, cuando forma parte de una seria convicción religiosa y siempre que no se obligue a los alumnos a seguirla ${ }^{96}$. Por otro lado, están excluidas las manifestaciones de opiniones políticas. En esta línea, considero muy significativa la sentencia del Tribunal Federal Administrativo prohibiendo que un profesor usara una pegatina contra el uso de energía nuclear ${ }^{97}$, que hemos mencionado anteriormente. En la misma línea, otra jurisprudencia de los años 80 referidas al uso por parte de algún profesor de la túnica roja de la secta de Baghwan Rajneesh ayuda a entender lo que sería adoctrinamiento y por tanto lo que constituiría un peligro concreto para los alumnos ${ }^{98}$. Estos últimos casos fueron resueltos en los años 80 por tribunales administrativos. En la doctrina se cita con frecuencia una de las sentencias, pero no se suele profundizar más sobre el problema. Por ello documentaré brevemente los hechos. La argumentación del Tribunal Federal Administrativo fue muy breve. Sin embargo, en la instancia previa del Land de Baviera el tribunal es más explícito sobre las razones para prohibir al profesor dar clases vestido con la túnica roja ${ }^{99}$. Se alega que la publicidad de las creencias es contraria a la neutralidad exigida a un profesor de un centro escolar. En este caso, se recoge que los padres y el consejo escolar fueron los que denunciaron al profesor. Los argumentos de la sentencia son técnicos y responden a la dogmática habitual de neutralidad de los funcionarios, especialmente en el ámbito educativo por la influencia del profesor en menores todavía no maduros en sus ideas. El profesor denunciado pertenecía a la comunidad de su iniciador Osho, inicialmente llamado Rejneesh Chandra Mohsen. Se puede afirmar con pruebas fechacientes que ese grupo es una secta destructiva. Su inciador, que falleció en 1991 fue un personaje conflictivo. Entre sus ideas estaba la promoción de la libertad sexual, la promiscuidad y la abdicación de la familia. Sus seguidores en general no trabajan, pero algunos lo hacen en la enseñanza, como medio de captar adeptos. Viven de los cursos y las terapias que imparten y del dinero de sus donantes. En 1988 la policía descubrió en la comuna de Rejneesh un arsenal de metralletas. En ese sentido, el uso de la túnica Bhagwan tiene bastante más significado que ser una mera vestimenta religiosa, porque quien

\footnotetext{
${ }^{96}$ En esta sentencia, se presentaron como parte interesada entre otros la comunidad de musulmanes alevitas. Están en contra del uso del velo por parte de maestras y empleadas de las escuelas públicas y les parece contrario a la neutralidad del Estado, que ellos entienden en sentido estricto. Creen que la presencia de maestras musulmanas con velo puede presionar a las alumnas musulmanas a verse obligadas a usarlo, en lugar de elegir libremente. También las familias musulmanas pueden sentirse más respaldadas para obligar a sus hijas a usar el velo. En el caso de la religión alevi, las mujeres no tiene obligación de llevar velo, y a veces las alumnas alevis se ven presionadas en la escuela por otras compañeras musulmanas sunitas por no seguir esa práctica. (BVerfG, 27.01.2015, 1 BvR 471/101 BvR 1181/10, § 68.6).

97 BVerwGE 84,92.

98 BVerwGE, DVBl, 1988, 698 (699). Las instancias anteriores VG Münich. No se admitió el recurso constitucional, 2 BvR 5999/88. 02.18.1986, AZ- 5 k 8500752 y VGH Baviera, 06.04.1987 AZB 38601 626. Otro caso se dió en Hamburgo, OVG Hamb, NVwZ 1986, 496.

99 VGH Baviera, 06.04.1987 -AZB 38601626.
} 
la portaba también adoctrinaba a los alumnos sobre esa filosofía, con esos contenidos, intentando atraer a los más débiles. En este sentido el Bhagwanismo se convierte en una secta peligrosa y más con una posible influencia y manipulación de menores. Por tanto, el análisis de una prenda religiosa debe tener en cuenta el contexto y la conducta de quien lo usa. De ahí por ejemplo, la diferencia entre el uso de esa túnica roja, frente al velo o a un hábito religioso cristiano. Si bien, tanto en esos casos, como en todos, hay que estar atentos a que no se produzcan intentos de imponer las ideas a los alumnos ${ }^{100}$.

El TC deja claro, como lo hizo en el caso Ludin que el Estado no se identifica con los signos religiosos que utilizan cada uno de sus empleados ${ }^{101}$ (en la doctrina éste tema sigue siendo controvertido, pero la jurisprudencia del TC avanza en la dirección de no identificar ambas cosas y de salvar el derecho de libertad religiosa de sus empleados) ${ }^{102}$. No obstante los votos particulares siguen identificando al funcionario con el Estado.

En cualquier caso, no se puede priorizar sin más el ejercicio de los derechos de libertad religiosa positiva de un profesor, sino que es crucial tener en cuenta el contexto, el lugar concreto, el centro escolar, el perfil del alumnado, así como la posible influencia positiva o negativa en las alumnas musulmanas, el ambiente de los alumnos entre sí, su lectura de los símbolos, tengan o no para el portador determinado significado. Habrá que tener en cuenta todos los elementos en juego ${ }^{103}$.

Habiendo investigado de cerca la impartición de las asignaturas de Politik y Sozialkunde en las escuelas alemanas, se observa que hay mucho más peligro de adoctrinamiento a través de las clases y de los manuales en todas las materias, que no por la materialidad de usar o no un velo. Además cuando se ve el velo, ya los alumnos toman sus medidas mentales restrictivas ante la posible influencia de las ideas de esa profesora, mientras que no ocurre lo mismo en otros muchos casos. Por otro lado, hasta los manuales alemanes que he revisado (que han sido muchos) de estas materias tienen en ocasiones marcadas tendencias, y algunos están muy lejos de ser objetivos

100 También otra sentencia que marca los límites, aunque se refiere a un alumno musulmán que solicita rezar en el pasillo de un instituto en Berlín, cuyo derecho se deniega porque ha habido conflictos concretos en ese instituto, es significativa para estudiar las fronteras entre unos casos y otros, sin mezclarlo todo (de la que trataremos infra).

101 BVerfGE 108, $282<305>$.

102 Comparto en este punto las opiniones de FRINGS, D. o.c., passim y SACKSOFSKY, U. o.c., passim, sobre los DF de los funcionarios, aunque estén limitados. Descontentos con esta nueva tendencia de la jurisprudencia del BVerfG, DEPENHEUER, O. (1992). «Die «volle persönliche Verantwortung» des Beamten für die Rechtmäßigkeit seiner dientlichen Handlungen - Zum Spannungsverhältnis zwischen Eigeverantwortung und Verwaltungshierarchie», DVBl, p. 404 y ss. DEPENHEUER, O. (2005). «Das öffentliche Amt», en ISENSEE, J. y KIRCHHOF, P. (eds.), Handbuch des Staatsrechts, tomo 3. Demokratie, Bundesorgane, 3. Aufl. Heidelberg, Beck, §36, Rn. 19. LEUZE, D. (1998). «Das allgemeine Persönlichkeitsrecht des Beamten», ZBR, p. 187 y ss.

103 ENNUSCHAT, J. «Förderung der Kirche durch den Staat», en LISTL, J. Y PIRSON, D. (2017). Handbuch des Staatskirchenrechts der Bundesrepublik, Zweiter Band, Berlin, Duncker and Humblot, $\S 31$. 
o neutrales. Esto ocurre en unos manuales que pasan por supervisión de las consejerías de educación de cada Land ${ }^{104}$.

\section{VI.2. El derecho de los padres (art. 6. 1 LF)}

Por un lado, se debe de tener en cuenta la situación de vulnerabilidad de los menores y de especial sujeción a la autoridad del profesor, pero por otra parte, eso no implica que los padres, amparados en una presunta libertad de educación pretendan discriminar a los profesores por razones de religión o de raza ${ }^{105}$. En medio de ambos se encuadra la autoridad del Estado en ejercicio de su misión educativa. Ante los funcionarios que pertenecen a religiones minoritarias, en el caso de que el profesor respete los límites establecidos y actúe correctamente, el Estado se debe de plantear si debe ceder ante padres que quieran discriminar a los profesores, en este caso profesoras, en el fondo en el caso de que sean de otras culturas y religiones, provengan de familias con origen en la inmigración (mit migrationshintergrund). Visto desde esa perspectiva, también los padres y alumnos tienen una obligación jurídica de respeto al ejercicio de los DF de los profesores (reconociendo que nos movemos en un ámbito en el que los alumnos están en una situación de inferioridad frente al profesor y que se debe ser muy cuidadoso para evitar que el maestro abuse de su situación de superioridad $)^{106}$. En la práctica en Alemania, los problemas jurídicos relacionados con el uso del velo por profesoras han surgido por prohibiciones de los legisladores y de las administraciones y no por protestas de los padres o de los alumnos.

Si bien la discusión se centra en cómo entender la neutralidad del profesor, también el elemento de los usuarios o de la opinión de los padres como clientes de la escuela, entroncaría con las recientes discusiones en la jurisprudencia del Tribunal de Justicia de la Unión Europea sobre si el empleador debe de plegarse a opiniones de sus clientes sobre sus trabajadores, si dichas opiniones fueran racis-

104 ELÓSEGUI, M. (2011). «La legislación vigente sobre la asignatura de Politik en las escuelas alemanas», Revista de Estudios Políticos, n. ${ }^{\circ}$ 154, Octubre/Diciembre, pp. 71-109. ELÓSEGUI, M. (2011).«La mente del legislador en los programas de la asignatura de educación política en las escuelas alemanas, en la LOE y en la legislación educativa de la CAPV», Revista Vasca de Administración Pública, n. ${ }^{\circ} 89$, enero-abril, pp. 265-310.

105 SACKSOFSKY, U. o.c., p. 806, opina que no siempre puede prevalecer lo que piensen los padres, en caso de que estos sean racistas (más concretamente de extrema derecha) y en la hipótesis de que protestaran por tener un profesor judío o una profesora con fisonomía que denotara que no es alemana de origen.

106 Voto particular, aa). Los dos jueces disidentes no consideran realista la opinión mayoritaria del BVerfG según la cual el hecho de que los profesores lleven una vestimenta con connotación religiosa no afecte a la libertad religiosa negativa de los alumnos, dada la especial situación de autoridad de los maestros y que los alumnos no tienen madurez de juicio. Por ello, es mejor limitar la indumentaria en el recinto del colegio. 
$\operatorname{tas}^{107}$. Ciertamente ahí nos movemos en el ámbito privado y no en el público, pero mutantis mutandis, el Estado como empleador no debería permitir plegarse a una discriminación racista contra sus profesores ante posibles demandas de los padres, insisto, sólo si estas fueran las razones. Como señala Tonio Klein, los prejuicios y los sentimientos discriminatorios no pueden tener protección constitucional ${ }^{108}$.

Curiosamente en Alemania, la jurisprudencia mayoritaria es de padres contra el centro escolar por materias impuestas desde el Estado mismo, que no respeta la diversidad de pensamiento de algunos padres, no sólo musulmanes, sino cristianos $^{109}$. Un tema controvertido y recordado en esta sentencia es que el derecho de educación no pertenece en exclusiva a los padres, sino que el Estado ejerce su misión educativa junto con los padres. La misión educativa del Estado (Art. 7, 1, LF) se ejerce a través de la supervisión de todo el sistema escolar ${ }^{110}$. En Alemania la escuela juega un papel muy fuerte en la integración y educación de los alumnos y «aborrece» cualquier señal de creación de sociedades en paralelo o guetos dentro de la escuela o fuera de ella.

Según el BVerfG para contraponer la libertad negativa como impedimento para el ejercicio de otro DF se requiere un juicio de valor sobre el caso concreto y por ello una norma general prohibitiva no sería conforme a la Constitución ${ }^{111}$. Además, el

${ }^{107}$ Por ejemplo, la sentencia TJUE, 10.7.2008 - RS. C-54/70, sobre un empresario constructor de puertas de garaje en Bélgica que declaró en la radio que no contrataba a empleados de origen marroquí porque sus clientes no se fiaban de ellos. Más recientemente, en la sentencia del TJUE sobre el uso del velo en los casos Asma Bougnaoui, Case C-188/15, de 13 de julio de 2016, sobre una cuestión prejudicial planteada por la corte de casación francesa, el TJUE señala que no se puede discriminar a una empleada que usaba el velo porque lo hayan solicitado los clientes. A diferencia de otro caso, referente a Bélgica, en el que la empresa tenía previamente un código de vestimenta que prohibía el uso del velo. Si bien según el Tribunal Europeo de Derechos Humanos la imagen corporativa y los códigos de vestimenta no pueden anteponerse al respeto de los DF de los trabajadores (TEDH, Eweida y otros c. Reino Unido). Vease, ELÓSEGUI, M. (2016). «El principio de proporcionalidad de Alexy y los acomodamientos razonables en el caso del TEDH Eweida y otros c. Reino Unido/ Das Verhältnismässigen anpassungen in der Entscheidung des Europäischen Gerichtshofs für Menschenrechte (EGMR) im Fall Eweida und Andere gegen das Vereignigte Königsreich», en ELÓSEGUI, M. (Coordinadora), Los principios y la interpretación judicial de los Derechos Fundamentales. Homenaje a Robert Alexy en su 70 aniversario, Zaragoza, Fundación Giménez Abad, Alexander von Humboldt Stiftung y Marcial Pons, pp. 157-186 y pp. 333-365. Curiosamente, las dos abogadas generales, Sharpstom y Kokott respectivamente, han hecho razonamientos muy diferentes, aunque sean coincidentes en algún punto. Tema que no podemos tratar en este artículo, y lo haremos en un futuro. De momento, sólo nos interesa destacar que los derechos de los padres en cuanto usuarios de los servicios públicos tendrían un límite en la prohibición de discriminar del art. 3 de la Constitución alemana.

${ }_{108}$ KLEIN, T. o.c., p. 469. Quien remite a la sentencia del empresario de garajes belga en p. 468, nota 48 .

109 ELÓSEGUI, M. «El concepto jurisprudencial de acomodamiento razonable. El Tribunal Supremo de Canadá y el Tribunal Europeo de Derechos Humanos ante la gestión de la diversidad cultural y religiosa en el espacio público», Anuario de Filosofía del Derecho, N. ${ }^{\circ}$ 30, 2014, (Ejemplar dedicado a: Tiempos de crisis, nuevos escenarios del pensamiento jurídico), pp. 69-96.

110 BverfGE 108, 282, <301>.

111 Véase H. A. WOLFF, o.c., p, 490. 
derecho de libertad negativa de los padres y de los alumnos no se lesiona por el hecho de que una profesora lleve un velo. Ese derecho no garantiza el no verse confrontado con una vestimenta religiosa de un profesor que sea de otra religión o creencia. El caso del ejercicio concreto del derecho de un profesor (que no representa al Estado) puede verse limitado si hay una reclamación concreta porque el comportamiento de un profesor no respete el derecho de los niños. Entonces se estudiará ese caso concreto ${ }^{112}$.

\section{VI.3. El principio de neutralidad abierta de la educación estatal y el trato paritario de las religiones}

Como ya indicamos, a nuestro juicio el tema clave de la sentencia reside en la apuesta clara que realiza el primer senado del BVerfG por una neutralidad abierta, a diferencia de las ambigüedades sembradas en el caso Ludin, lo que fue muy criticado por la doctrina alemana. El BVerfG afirma que el Estado es el hogar de todos los ciudadanos (art, 4.1., art. 3.3, art. 33.3 LF, art. 136.1 y 4, art 137.1 WRN en conjunción con el art. $140 \mathrm{LF}$ ) y que por tanto, según la LF debe estar abierto a la diversidad de creencias, basadas en la dignidad de la persona y en el libre desarrollo de la personalidad. No hay una religión del Estado (Gebot der Nichtidentifikation) y está prohibido privilegiar ciertos credos, así como la exclusión de otras religiones. El Estado tiene una obligación constitucional de trato paritario de las religiones ${ }^{113}$. A lo que añadimos, que todo ello no debe hacernos olvidar que tanto la Constitución alemana, así como varias de las constituciones autonómicas citan a Dios en su preámbu$10^{114}$, lo que indica con claridad que el modelo alemán de relaciones Iglesia-Estado no es un modelo laicista.

Según el Tribunal: «La neutralidad ideológica-religiosa del Estado no ha de ser entendida como un distanciamiento en términos de una estricta separación entre la Iglesia y el Estado, sino como un proceso abierto y transversal del derecho de libertad de creencias con un trato igualmente amigable para todos los credos» ${ }^{115}$. Del art. 4.1 y 2 de la LF también se deriva un ejercicio en sentido positivo, para asegurar un ejercicio activo de las creencias. El Estado no se debe identificar con ningún credo religioso particular o con una ideología.

Esto también se aplica al ámbito de la escuela. A su vez no se excluye la enseñanza de la religión de la escuela pública, ni la referencia a valores cristianos, pero

${ }^{112}$ BVerfG, 27.01.2015, 1 BvR 471/ 101 BvR 1181/10, § 107. Esta idea ha sido criticada por parte de la doctrina, ya que ven negativo el hecho de delegar la responsabilidad de la denuncia en los padres o los propios alumnos.

113 BVerfG, 27.01.2015, 1 BvR 471/ 101 BvR 1181/10, § 109, citando BVerfGE 108, 282, $<299>$. Destacan que el BVerfG haya dejado claro una interpretación positiva de la neutralidad, TRAUB, T. o.c., p. 1340. También MUCKEL, S. en FRIAUF/HÖFLING, BlnKomm-GG, Art. 140, $\mathrm{Rn}, 31 \mathrm{ff} . \mathrm{mwN}$.

114 WOLFF, H.A. o.c., p. 491.

115 BVerfG, 27.01.2015, 1 BvR 471/ 101 BvR 1181/10, § 110. 
debe estar abierta a otros valores filosóficos y religiosos ${ }^{116}$. Esta apertura de la escuela a los diversos valores religiosos es compatible con la neutralidad religiosa exigida por la $\mathrm{LF}^{117}$.

En síntesis, la interpretación del BverfG rechaza un modelo de laicismo francés propio de los colegios franceses, distinguiendo el secularismo o la aconfesionalidad del laicismo. Si bien, varios autores han mostrado su preocupación sobre las posibles derivas de la reducción de los valores cristianos en la escuela ${ }^{118}$. Como señalamos al inicio, ciertamente existe un peligro de ir reduciendo la religión en las escuelas a una religión civil, que sustituya la enseñanza de la religión confesional ${ }^{119}$. La religión civil no debería ser un sustituto de la religión confesional, como podría acabar ocurriendo en la nueva legislación del Land de Hamburgo, que ya hemos indicado. Cosa diferente sería admitir que existen unos valores comunes a las distintas religiones. Pero, una vez más, tampoco una asignatura de historia de las religiones debería sustituir la posibilidad de recibir clase de religión confesional. Como pone en evidencia Ladeur existe también el peligro de reducir la religión a algo interior (innerlichte Form zu gehen) y a algo individual, en la línea del protestantismo (entchristinisierten, auf Moral reduzierten Protestantismus) ${ }^{120}$. Esta idea repercute no sólo en los Länder de tradición católica, por un lado, que también y por eso se resisten, si no que por otro, se dirige también a los musulmanes y a otras religiones que marcan mayormente la vida cotidiana del creyente, y que recuerdan la creencia en la transcendencia, lo que molesta en una sociedad más laicista o más roussoniana, que reduce los lazos sociales a lazos políticos y culturales, y en el fondo quiere dejar de lado la religión.

116 BVerfGE 41, $29<51>$.

117 Como señala LADEUR, K.H. «Das islamisches Kopftuch...», pp. 636-637. El mismo calendario de las vacaciones de las escuelas responde a un calendario de las fiestas cristianas, Navidad, Semana Santa, los domingos como día no festivo. Además en las escuela alemanas tanto públicas como privadas se imparte educación religiosa confesional católica y protestante a los alumnos que lo desean desde primaria. Es impartido por los propios funcionarios que se preparan también en la universidad con asignaturas de religión protestante o católica. Ahora también de religión ortodoxa e islámica. A partir de ahora también se ofrecerá teología islámica en varias universidades alemanas para que los profesores funcionarios puedan impartir estas asignaturas, sin necesidad de que lo hagan personas que no tengan una licenciatura universitaria. Además estas asignaturas de religión confesional, incluida la clase de Corán será impartida en alemán. Véase UNGERN-STENBERG, A VON. o.c., passim, BAUER, J. o.c., passim y DEMEL, M. o.c., passim.

118 STARCK. C. señala de un modo claro esta idea en «La libertad religiosa en Alemania como libertad positiva y negativa», o..c, p. 70: «Si el Estado expulsara completamente la creencia religiosa fuera de la clase de religión confesional expresamente garantizada por el Derecho Constitucional (Art.7, párrafo 7, LF), recurriendo a su obligación de neutralidad y la libertad de culto negativa, finalmente acabaría siendo una escuela laicista».

119 Ya hemos señalado supra la puesta en marcha en el Land de Hamburgo de una clase de religión para todos, pero que sustituya a las actuales asignaturas de religión confesional.

120 LADEUR, K.H. «Das islamische Kopftuch...», o.c., p. 637. 


\section{EL EXAMEN DE CONSTITUCIONALIDAD DEL ARTÍCULO 57 DE LA LEY DE EDUCACIÓN DE RENANIA DEL NORTE WESTFALIA}

A continuación vamos a estudiar el análisis que desarrolla el BVergG de los cuatro incisos del art. 57. 4 de la Ley de Educación de Renania del Norte Westfalia, ejerciendo su competencia de control de la constitucionalidad de las leyes de los Länder.

\section{VII.1. Interpretación restrictiva del inciso 1 del art. 57.4. Sólo ante peligro concreto}

El Tribunal interpreta el contenido del inciso 1 del mencionado artículo y lo considerará conforme a la LF sólo si se hace una interpretación restringida. En resumen se podría restringir las manifestaciones religiosas e ideológicas de un profesor o profesora si hubiera una amenaza concreta o perturbación de la paz escolar o de la neutralidad del Estado, razonablemente justificada y sólo en los siguientes casos:

Primero; en el caso de que un profesor concreto no respetara el límite legal de no adoctrinar, es decir que hiciera manifestaciones verbales sobre sus creencias o ideología y se produjera tal conflicto con los padres o con los alumnos de más edad y eso impidiera impartir la docencia (cumplir con la misión educativa de la escuela). En este caso, se le puede prohibir esa conducta externa. Esto entraría dentro de las restricciones del art. 57, 4 inciso $1^{121}$.

Pero esta infracción no se produce por el simple hecho de llevar una prenda religiosa. El llevar un velo islámico no supone un riesgo concreto y carece por si mismo de capacidad evangelizadora ${ }^{122}$.

Una segunda situación se daría, si en ciertas escuelas o zonas se produjeran continuos y frecuentes conflictos. Entonces se podría entender que en esos centros se hiciera una prohibición temporal hasta que se desapareciera el conflicto. Serían soluciones locales y temporales con la ayuda de una autorización legal suficientemente concreta $^{123}$. Esta solución tan indeterminada ha sido también criticada por parte de la doctrina, especialmente por quienes están a favor de las leyes generales prohibitivas $^{124}$. Algunos supuestos que servirían para entender a qué tipo de situaciones se refiere el tribunal ya se han dado y han sido judicializados. Por ejemplo, en un insti-

121 BVerfGE, 27.01.2015, 1 BvR 471/ 101 BvR 1181/10, § 117.

122 Idem, § 113. B. Una vez más crítico VOLKMANN, U. o.c., p. 1085. Según su opinión sólo por llevar el velo se hace ya proselitismo. Como contraste, Ladeur no es crítico con el velo en sí, pero teme una posible creciente islamización ante la llegada de estos 800.000 refugiados musulmanes. Véase, LADEUR, K.H. «Burkaverbot in der Schule...», o.c., passim. Es partidario de hacer una ley prohibitiva del burka y del niqab (que tapa la cara menos los ojos) para alumnas y profesoras. Pero no del velo que deja ver el rostro.

123 BVerfG, 27.01.2015, 1 BvR 471/ 101 BvR 1181/10, §114 C.

124 También los votos particulares. En BVerfG, 27.01.2015, 1 BvR 471/ 101 BvR 1181/10. 
tuto de Berlín, «un alumno musulmán pidió rezar durante las pausas en las instalaciones de la escuela. El Tribunal Administrativo Federal ${ }^{125}$ confirmó la decisión de la dirección de prohibir el rezo alegando que en esta escuela en concreto el acto de rezar podría poner en peligro la paz interna del establecimiento» ${ }^{126}$.

La razón es que en ese instituto había habido conflictos anteriormente porque alumnos musulmanes molestaban a otros musulmanes de distintas tendencias o a los alumnos cristianos, con mobbing, insultos y ofensas. El tema llegó al OVG Berlin-Brandenburg ${ }^{127}$ y más tarde al Tribunal Administrativo Federal, BverwG ${ }^{128}$. Por ejemplo, una alumna de origen musulmán que no quería vivir el Ramadán fue insultada por otros compañeros musulmanes, también hicieron burla de símbolos judíos e insultaron a cristianos llamándoles «Mierda de cristianos» ${ }^{129}$.

Los argumentos del Tribunal Administrativo Federal fueron que: «Debido a la composición heterogénea del alumnado, se habían producido conflictos, a veces muy violentos, entre los alumnos, motivados por reproches vertidos contra otros compañeros por no cumplir con las reglas de comportamiento que se deducen de una determinada interpretación del Corán, como el mandamiento de cubrirse la cabeza con un pañuelo, de observar el ayuno, de realizar los rezos, de no comer carne de cerdo, de evitar «conductas inmorales», de no «llevar ropa inmoral» y de evitar cualquier contacto personal con compañeros «impuros». Por estos motivos se han producido casos de acoso psicológico, ofensa, especialmente con contenido antisemita, amenaza y discriminación sexista» ${ }^{130}$.

También se había intentado habilitar en ese mismo instituto un lugar de culto que hubo que suprimir: «En el pasado, se había instalado una sala común de cultos en la escuela que, sin embargo, tuvo que volver a cerrarse a raíz de disputas verbales entra alumnas que usaban pañuelo y otras que no, y tras la negativa de los chicos de rezar conjuntamente con las chicas» ${ }^{131}$.

Sin embargo, para Ennuschat, coincidiendo con Eckart Klein, en este caso se pospone el derecho de libertad positiva de este alumno, que no es el causante de los conflictos que se dan en su instituto. Además critican una vez más que se vaya cambiando de criterios. Si bien este caso lo resuelve el Tribunal administrativo y no el TC. Pero estos autores refiriéndose a la ponderación realizada por el BverWG comentan la diversidad de criterios al dar peso a los derechos porque si por fin se ha permi-

125 BVerwGE, 141, 223, Tribunal Administrativo Federal, Sentencia del 30 de noviembre de 2011-6 C20/10, NVwZ 2012. Confirmó la sentencia del OVG de Berlín.

126 ENNUSCHAT, J. (2012). «La cooperación entre el Estado y la Iglesia en escuelas y universidades», en ELÓSEGUI, M. (Coord.), La neutralidad del Estado y el papel de la religión en la vida pública en Alemania, o.c., p. 95.

127 OVG Berlin-Brandenburgo, NVwZ 2010, 1310.

128 BVerwGE 141, 223, NVwZ 2012, 162, LKV 2012, 27.

129 TRAUB, T. o. c., p. 1339.

130 BVerwGE 141, 223, §44. Comentarios a la sentencia en MUCKEL, S. (2012). «Verbot des rituelles Gebets in der Schule», JA, pp. 272-279. HUFEN, F. JUS, (2012), pp. 663-665.

131 BVerwGE 141, 223, \$58. 
tido, aunque con ciertas restricciones, la posibilidad de realizar alguna oración cristiana en las escuelas, prevaleciendo el derecho de libertad positiva, también debería prevalecer en el caso de ese alumno, si es posible organizarlo.

Por insistir en ejemplos concretos de zonas conflictivas, la sentencia del Landerarbeitsgericht de Berlin-Brandenburg, en su reciente fallo del 9 de febrero de 2017, también cita lugares concretos con tensiones como Kreuzberg, Neukölln, Wedding der Fall en las que hay escolares con orígenes en la inmigración de mayoría musulmana. Sin embargo hay otras zonas con el mismo número de alumnos musulmanes en las que no se registra ningún conflicto, como Frohau, Dahlem, Grunewald o Schmargendorf ${ }^{132}$.

Volviendo a la propuesta del BVerfG, si se diera la segunda de estas situaciones, en el caso de que el uso del velo de una profesora acrecentara las tensiones ya existentes, las autoridades educativas pueden buscar una solución para el profesor afectado encomendándole una función pedagógica alternativa.

Con posterioridad a la sentencia del primer Senado del BVerfG el 9 de febrero de 2017, el Land de RNW ha vuelto a debatir en el Parlamento la posibilidad de legislar sobre lo que se entiende por peligro concreto y sobre la posibilidad de declarar algunas zonas como más conflictivas para establecer esas prohibiciones. Los dictámenes de académicos presentados en una sesión, así como la opinión de las asociaciones de padres, ONG's, confesiones religiosas vuelven a ser significativos de la divergencia presente en la sociedad alemana. Entre los académicos tanto Ennuschat como Muckel desaconsejaron legislar nada nuevo ${ }^{133} \mathrm{y}$ argumentaron que lo adecuado es aplicar sin más lo que ha señalado el BVerfG en su sentencia.

En la doctrina, algunos como Wolff o Sacksofky han criticado que el BVerfG estaría permitiendo, según esto, prohibir usar el velo, cuando exista peligro concreto. Para el primero no es coherente con todo lo sentado en la sentencia que se termine por permitir una prohibición del velo en las profesoras ante un peligro concreto, en los casos en los que no ha ido acompañado de una conducta verbal ${ }^{134}$. Sacksofky concluye que la paz escolar en sí no es un bien constitucional, luego no es apta para hacer válida una prohibición ${ }^{135}$. Según la misma autora, después de esta sentencia se puede

132 Landesarbeitgsgericht Berlin-Brandenburg, 09.02.2017 -14 Sa 1038/16, P. 34

133 Landtag Nordhrein-Westfalen, 16 Whalperiode. Ausschuss für Schule und Weiterbildung. Auschussprotokoll. Apr 16/907. 13 de mayo de 2015. Düsseldorf. Haus des Landtags, 42 pp. AnneKathrin Kenkmann (Juristiche Fakultät, Ruht-Universität, Bochum), presenta la opinión del profesor Ennuschat. Se concluye que podría hacerse una ley con pautas que definan el peligro concreto, pero lo desaconseja. Que es mejor poner otras medidas, como por ejemplo, que en la docencia se trasmita con claridad la igualdad entre hombres y mujeres previstas en el artículo 3 de la LF. Por su parte Stephan Muckel señala que a consecuencia de la resolución del BVerfG sería posible hacer reglamentos concretos (Verordnungsermächtigung) para colegios o zonas concretas, pero él no es partidario de ello porque puede traer consigo más problemas que soluciones. En su opinión, anulado el inciso 3, los incisos 1, 2 con la interpretación restrictiva) y el 4 pueden permanecer como están.

134 WOLFF, H.A. o.c, p. 492.

135 SACKSOFSKY, U. o.c., p. 806. 
emitir una nueva falsa señal que conduzca a los Länder a que construyan una dogmática del peligro concreto $^{136}$. Pero de momento, como ya hemos señalado, esto no ha sucedido y ya los parlamentos de Berlín ${ }^{137}$, Hesse y Renania del Norte han debatido sobre el tema y no tienen intención de incluir nueva legislación prohibitiva, ni que defina el concepto de peligro concreto.

Por otro lado, la cuestión de medidas que injieren en las libertades en momentos de crisis, como por ejemplo, por cuestiones de seguridad del Estado ante el terrorismo, podrían adoptarse en supuestos extremos justificados, pero deben ser transitorias y eliminarse $^{138}$. En este sentido, resulta ilustrativo, el fallo del BVerfG en $2006^{139}$ a favor de un estudiante universitario marroquí contra las medidas tomadas por el Estado alemán a través de «una orden, que obligaba a los registros civiles, al registro central de extranjeros y a las universidades a transferir a la policía datos de varones de entre 18 y 40 años, concretamente sobre su credo, su país de origen y su carrera universitaria» ${ }^{140}$. Precisamente el BVerfG ha utilizado la doctrina del peligro concreto para negar la proporcionalidad de esta medida empleada por el Estado alemán, «al considerarla una intervención «de relevancia considerable», esto es, una intervención grave en el derecho fundamental a la autodeterminación informativa. Para su justificación bastaría un peligro concreto, pero no una «amenaza general», es decir, un peligro general abstracto» ${ }^{141}$.

Volviendo a nuestra sentencia, el BverfG considera que la finalidad de la medida de prohibición del velo, alcanzar la paz escolar, es légitima, pero el medio utilizado es desproporcionado e inadecuado, mientras que los votos particulares hacen una

136 Idem, p. 807.

137 En el 2015 la fracción del partido socialista de Berlín en el Parlamento de ese Land consideraba que la Ley de neutralidad de Berlín era conforme a la LF. Como contraste el partido WPD (WasserParteiDeutschland) quería cambiar esa ley para permitir el uso de símbolos o vestimentas religiosas en los funcionarios. De todos modos con el fallo del Bundesarbeitsgericht de Berlín-Brandeburgo queda claro que desde la nueva Resolución del BVerfG no se puede prohibir los símbolos religiosos en funcionarios. Por mucho que en la instancia anterior del Arbeitsgericht el juez alegase que la resolución se refería al Land de RNW y que no afectaba al Land de Berlín. La vinculación para otros Länder de las sentencias del TC en declaraciones de inconstitucionalidad de normas de algún Land concreto es un tema controvertido en el que no nos vamos a detener ahora. Para una crítica de la Ley de Berlín véase, LÖWENBRÜCK, L.S (2016). «Wie neutral sind Berlins Schulen?», Heinrich Böll Stiftung, Migrationspolitisches Portal, 22 de abril de 2016. Disponible en: https://heimatkunde.boell.de/2016/04/22/ wie-neutral-sind-berlins-schulen

138 WOLFF, H.A. o.c., p. 490. En tiempos concretos de terrorismo caben más medidas preventivas por parte del Estado, pero estas deben ser proporcionales, pero no se pueden justificar ya como permanentes.

139 BVerfGE 115, 320.

${ }^{140}$ ALEXY, R. (2016). «Un concepto no positivista de Derecho Fundamental. Sobre la relación entre Derecho y moral», en ELÓSEGUI, M. (Coord.), Los principios y la interpretación judicial de los Derechos Fundamentales. Homenaje a Robert Alexy en su 70 Aniversario, o.c., p. 43.

141 ALEXY, R. ídem. Citando BVerfGE, 115, 320 (348) y (364). Con el voto disidente de la jueza Haas, quien da más peso en este caso al interés general que a la lesión del derecho a la privacidad. 
ponderación inversa, a favor del legislador y en contra del peso que el voto mayoritario otorga a los derechos individuales de las dos recurrentes ${ }^{142}$.

Para Wolff se debería ir más allá y huir de prohibiciones, incluso en los casos señalados, ya que la concordancia práctica no es abstracta, sino que debería llevar a compromisos en la práctica ${ }^{143}$. Por otro lado, la posibilidad apuntada por el TC de buscar una medida alternativa y desplazar al profesor a otro lugar, es prácticamente inviable, una utopía.

El BVerfG concluye que una restricción de la libertad religiosa sólo puede estar justificada después de una ponderación razonable entre los principios constitucionales en juego, en la que se demuestre que existe un peligro concreto. Precisamente la escuela pública no confesional debe ser tolerante con los estudiantes de otras religiones y creencias y estar abierta a cristianos, musulmanes y personas de otras confesiones religiosas o ideológicas ${ }^{144}$. Se debe vivir una realización efectiva de los DF en la escuela pública. También para el uso de ropa asociada a otras religiones como el velo, la kipá judía o el hábito de las monjas o símbolos como la cruz ${ }^{145}$.

Esto reafirma el modelo que propone el BVerfG de neutralidad abierta y la idea de visibilizar las diferencias y no ocultarlas. También el hábito de las monjas por tanto si lo usan a título personal cuando imparten la asignatura de religión u otras asignaturas debe ser respetado. Por tanto, sólo se pueden prohibir las manifestaciones religiosas de los profesores, previstas en el art. 57, 4, inciso 1 de la Schulg en los casos en que haya un verdadero riesgo que esté motivado y justificado. Esto se aplicara por igual a todas las religiones, y no sólo al velo islámico. En los casos concretos examinados, no existe un peligro concreto, luego la prohibición no está justificada. Incluso aceptando que el gorro que usa una de las recurrentes es equivalente a un velo islámico (para el espectador objetivo imparcial y por la intención manifestada de la propia implicada) no se le puede atribuir una finalidad evangelizadora o proselitista. Además el uso del velo entre las mujeres musulmanas en Alemania no es raro, incluso si no es apoyado por la mayoría de las mujeres musulmanas ${ }^{146}$. En suma, pertenece a la vida cotidiana del alumnado ver esta diversidad.

142 BVerfG, 27.01.2015, 1 BvR 471/ 101 BvR 1181/10, Voto particular, §9. En la misma línea WOLKMANN, U. p. 1086.

143 WOLFF, H.A. p. 490

144 KLEIN, E. (2016). «Religionsfreiheit und öffentliche-Schulen», RdjB, 1, pp. 13-29. No comparte esta opinión, ya que según él no es competencia del tribunal constitucional decidir qué modelo de neutralidad abierta debe ser el que esté presente en las escuelas porque esa es una opción que debería quedar en manos del legislador, de las administraciones y de los ciudadanos.

145 BVerfG, 27.01.2015, 1 BvR 471/ 101 BvR 1181/10, § 115. El BVerfG recuerda la necesidad de ponderación en el caso concreto.

146 BUNDESANT FÜR MIGRATION UND FLÜCHTLINGE (Ed.). (2009). Muslimisches Leben in Deutschland- editado por Die Deutsche Islam Konferenz (la Conferencia alemana sobre el Islám), p. 194. MINISTERIUM FÜR ARBEIT, INTEGRATION UND SOZIALES DES LANDES NORDHREIN-WESTFALEN (Ed.). (2010). Muslimisches Leben in Nordhrein-Westfalen, editado por el Ministerio de Trabajo y Asuntos Sociales de Renania del Norte-Westfalia, p. 93. 


\section{VII.2. Análisis del inciso 2 del art. 57.4 SchulG RNW}

En relación con el inciso 2 del art. 57. 4 de la SchulG de RNW, en la decisión se hace una crítica sobre la presunción del legislador que sin citar el velo directamente en la norma, hace una presunción de que las mujeres que llevan velo no respetan los principios constitucionales, como el de dignidad humana y el de igualdad entre los sexos. Concretamente la norma presupone particularmente que las mujeres que usan velo defienden un modelo de relaciones entre mujeres y varones machista o patriarcal. En definitiva, contrario al modelo de igualdad defendido por la LF alemana ${ }^{147}$. En su argumentación el TC deja claro que se está interpretando y calificando una conducta desde un prejuicio o un estereotipo por parte del legislador primero, y de la administración que aplica esa norma después. No se puede asumir que todas las mujeres que usan velo no comparten los derechos constitucionales alemanes, concretamente los dos que ya hemos citado, la dignidad humana y el artículo 3 de la LF, y además atribuirles que no están dispuestos a respetar la libertad, los DF de los demás o el régimen democrático-liberal alemán. En suma, no se puede inferir del hecho de que una persona quiera seguir en esto su tradición o su identidad que por ello se distancie de los principios constitucionales ${ }^{148}$. El velo islámico no puede ser interpretado como un símbolo político del fundamentalismo islámico ${ }^{149}$. Ya hemos señalado que los motivos por los que las mujeres musulmanas usan el velo son muy diversos.

Este salto lógico que hace la norma del Land no es aceptable. En definitiva, hay una inferencia en el razonamiento del legislador, que no es conforme a la LF. Este análisis del TC es bastante valiente y de gran peso porque se posiciona ante un debate habitual en Alemania (y en muchos países) de una supuesta incompatibilidad entre ser musulmán y ser ciudadano occidental. Sería entender que casi todos los musulmanes que viven en Europa son antidemócratas. Es precisamente este tipo de asunciones racistas hacia los ciudadanos de segunda y tercera generación con origen en la inmigración las que son irrespetuosas con los principios constitucionales de igualdad de trato y de respeto a las personas de diversas religiones y culturas. A estos ciudadanos con nacionalidad derivada lo que se les debe exigir, como a los demás, es que respeten la Constitución y sus valores ético-político-jurídicos que son la base común que vincula a todos los ciudadanos alemanes.

El BVerfG considerará en relación con las decisiones de los tribunales especializados, que el Tribunal Federal de trabajo no ha hecho una aplicación restrictiva de los incisos mencionados porque no ha probado que existiera un peligro real a la seguridad escolar. En el fallo de esta última instancia judicial mencionada, la calificación

147 Sobre el modelo de igualdad presente en la LF véase ELÓSEGUI, M. (2003). Las acciones positivas para la igualdad de oportunidades laborales entre mujeres y hombres. Un análisis de la legislación alemana y la Directiva 76/207/CEE desde la teoría de la argumentación de Robert Alexy, Madrid, Centro de Estudios Políticos y Constitucionales.

148 TRAUB, T. o.c., p. 1340.

149 BVerfG, 27.01.2015, 1 BvR 471/ 101 BvR 1181/10, §118, 5. 
jurídica de la conducta de las demandantes en ambos casos se ha considerado contraria a la norma porque se ha asumido que una prohibición ante un peligro abstracto era legal. A su vez, en los hechos descritos, queda claro que no hay prueba de que hubiera existido ningún peligro concreto ${ }^{150}$. En suma, estos tribunales no protegieron el derecho de libertad positiva del ejercicio de la religión, que para ambas demandantes incluía el hecho de llevar la cabeza cubierta como un imperativo religioso. Según el BverfG, los citados tribunales no hicieron bien la ponderación al no dar el debido peso a este derecho, y sin embargo priorizaron el peligro potencial de lesionar la paz escolar, desplazando un DF de un modo desproporcionado. Además al interpretar que los art. 57.4 y 59 de la SchuldG de RNW «eran idóneos para legitimar la prohibición de expresiones religiosas que constituyesen un mero riesgo abstracto para la consecución de los fines perseguidos por la legislación educativa estatal, incurrieron en un vicio de insconstitucionalidad» ${ }^{151}$.

Por otro lado, la demandante que era profesora de turco había dado clases con el velo durante años sin que hubiera ningún queja por parte de los padres o de los alumnos. Por tanto, el despido es insostenible legalmente ${ }^{152}$. En el otro caso, la recurrente que usaba un gorro de lana también había trabajado durante años con velo, sin que se suscitara ningún problema, hasta que ante la entrada en vigor de la ley prohibitiva lo cambió por un gorro, por lo que tampoco recibió ninguna queja de los padres o alumnos, salvo de la propia administración educativa. Por tanto, estas sentencias vulneran los derechos de las demandantes al no hacer una interpretación restrictiva de los incisos 1 y 2 del art. 57, 4 de la Ley de Educación y vulneran el DF de libertad religiosa contemplado en el art. 4 de la LF.

En conclusión, para que el segundo inciso del art. 57.4 de la SchulG no sea inconstitucional debe interpretarse también de un modo restrictivo. Se aplica también esa interpretación restrictiva al art. $58 \mathrm{SchulG}$, que se refiere al personal no docente, pero que participa en los centros escolares, como los trabajadores sociales ${ }^{153}$.

\section{VII.3. La cláusula de privilegio de los valores cristianos y occidentales del art. 57.4.3 SchulG RNW}

A continuación el BVerfG realizará el control de constitucionalidad del inciso 3 de la SchuldG de RNW que va a declarar inconstitucional y decidirá su anulación. Adelantamos que el inciso 4 de esta norma, que es sobre los colegios confesionales y los colegios con ideario de centro es conforme a la Constitución.

El BverfG considera que el recurso de amparo de las demandantes contra el art. 57, 4 inciso 3 está fundado ${ }^{154}$. Por ello hace un examen de la constitucionalidad

150 Idem, $\$ 120$.

151 VALERO, M.J. o.c., p. 19.

152 BVerfG, 27.01.2015, 1 BvR 471/ 101 BvR 1181/10, § 121.

153 BVerfG, 27.01.2015, 1 BvR 471/ 101 BvR 1181/10, § 119.

154 BVerfG, 27.01.2015, 1 BvR 471/ 101 BvR 1181/10, § 123 
del inciso 3 del mencionado artículo, en el que se privilegian los valores o tradiciones educativas y culturales cristianas y occidentales, para concluir que esta norma es contraria al art. 3 de la LF y al art. 33. 3 de la LF. Como consecuencia de este inciso, que permite el uso de símbolos cristianos pero no de otros, la norma conduce a una discriminación de las demandantes que es contraria a la LF.

Esa diferenciación entre la religión cristiana y la judía frente a otras religiones no está constitucionalmente justificada ${ }^{155}$. Por ese motivo la redacción es contraria al artículo 3.3. frase 1 de la LF, según el cual nadie podrá ser perjudicado, ni favorecido a causa de su fe o de sus opiniones religiosas. Además no es conforme al art. 4.1 y 2 de la LF sobre el derecho de libertad religiosa y de creencias $^{156}$.

Esta argumentación es correcta, pero entra en un tema delicado. La omisión del BverfG de citar el preámbulo de la LF, quizá peca de omisivo ${ }^{157}$. Se debe dejar más claro que un modelo intercultural de relaciones amistosas entre el Estado y las religiones, debe ser especialmente respetuoso con la religión mayoritaria de Alemania, que es la cristiana. Una cosa es no discriminar a las religiones minoritarias y otra intentar marginar la tradición cristiana.

El Tribunal examina nuevamente el derecho de acceso en igualdad a la Administración pública, concluyendo que este inciso número 3, discrimina en el acceso a la función pública y es contrario a art. 33. De la LF.

El art. 33 de la LF sobre los funcionarios públicos, incluye el acceso en igualdad y sin discriminación al servicio público de los funcionarios y de los contratados laborales de la administración. También su articulado prohíbe la discriminación por motivos religiosos, protegidos en el art. 4.1 y 2 de la LF. El mandato constitucional obliga a una rigurosa igualdad de trato en el acceso y en la práctica del funcionariado, así como en su promoción interna ${ }^{158}$.

Aunque en la norma en ningún momento se menciona el velo islámico, a la luz del proceso legislativo queda claro que el objetivo de esa cláusula era tan sólo prohibir el uso del velo islámico por parte de las profesoras ${ }^{159}$. Las reclamantes alegan que

155 BVerfG, 27.01.2015, 1 BvR 471/ 101 BvR 1181/10, § 124 y $\$ 125$, a).

156 Comparto en este punto la opinión de Wolff, para quien una neutralidad específica unida a las especifidades regionales contradice las garantías igualitarias de los derechos fundamentales de cualquier ciudadano en Alemania (WOLFF, H.A. o.c., p. 491). A mi juicio, esta normativa pretende hacer compatible en un mismo artículo dos neutralidades distintas dependiendo del destinatario, una confesional para los creyentes cristianos y judíos, y otra distanciadora de las religiones para las profesoras musulmanas.

157 Cfr., ENNUSCHAT, J. (1998). «"Gott” und Grundgestez. Zur Bedeutung der Präambel für das Verhältnis des Staates zu. Religion und Religionsgemeinschaften», NJW, pp. 953-955.

158 BVerfG, 27.01.2015, 1 BvR 471/ 101 BvR 1181/10, §126. Ya en Ludin, BVerfGE 108, 282, $<298>$.

159 LTDricks 13/4564, p. 8; LTDrucks 14/569, p. 9. Es evidente que estas leyes sobre símbolos religiosos, incluida la de RNW buscaban prohibir sólo el uso del velo y para eso utilizaron una formulación sinuosa. Sostiene esta misma opinión SACKSOFSKY, U. o.c., p. 802. Una mayoría de la doctrina criticó la posibilidad que el segundo senado del BVerfG había abierto de leyes prohibitivas a raíz de la sentencia Ludin. 
esa distinción entre los valores occidentales, cuyos símbolos no quedan excluidos y otros símbolos está hecha con intención de favorecer a los miembros de las confesiones cristianas y judías frente a profesores de otras confesiones. Los materiales del proceso legislativo avalan que esa interpretación es correcta ${ }^{160}$.

La Constitución alemana no justifica una diferencia de trato ${ }^{161}$. Por tanto la prohibición de uso de símbolos religiosos debería ser paritaria. El TC toma postura clara contra alguna de las opiniones vertidas en la doctrina que negaban la idoneidad para ser funcionario alemán a las mujeres que llevaran velo especialmente para ser profesoras, amparándose estos últimos en los motivos, que hemos señalado antes, de que defienden una visión no igualitaria entre mujeres y hombres. Según el TC, esta justificación ya no puede prosperar ${ }^{162}$. No se puede justificar una diferencia de trato entre quienes tengan unos valores culturales cristianos occidentales y quienes no los tengan. Como ya señalé en mi artículo sobre el caso Ludin, lo exigible al funcionario es la lealtad a la Constitución alemana (esto incluye el respeto de los DF y al Estado de Derecho, fundamento de las democracias occidentales), con independencia de la religión que se profese. Una identificación del funcionario con la cultura occidental (incluido con el cristianismo) es discriminatorio por razón de religión. Si bien, el TC no hace referencia a la discriminación racial a lo largo de la sentencia, sino más bien a la discriminación por motivos religiosos, es indudable que en este caso en la mayoría de las mujeres musulmanas la discriminación religiosa va unida a una discriminación racial, basada en el hecho de su cultura de origen, no occidental, aunque haya excepcionalmente alguna sentencia relativa a una profesora alemana conversa al Islam ${ }^{163}$. Aunque las dos recurrentes ostentan la nacionalidad alemana, sus padres provienen de Turquía.

160 BVerfG, 27.01.2015, 1 BvR 471/ 101 BvR 1181/10, §127 b).

${ }_{161}$ BVerfG, 27.01.2015, 1 BvR 471/ 101 BvR 1181/10, §128, c).

162 BVerfG, 27.01.2015, 1 BvR 471/ 101 BvR 1181/10, § 129.

163 El Tribunal Administrativo de Stuttgart (VG Stuttgart), Urteil vom 07.07.2006, Az 18 K 3562/005), anuló la prohibición impuesta por las autoridades educativas a la profesora Doris Graber, alemana conversa al Islam, para que no usara velo en el colegio. Verwaltungsgericht, SZ (Stuttgarter Zeitung), 12 de julio de 2006. En esta ocasión el Tribunal falló a favor de la profesora e inaplicó la Ley vigente del Land argumentando que por aplicación del principio de igualdad, sin negar la validez de la norma, si se permitía a las religiosas dar clases con hábito y toca, del mismo modo se debía permitir a esa profesora dar clases con velo. Presseerklärung: http://vgstuttgart.de/servlet/PB/ menu/1200794/index. html?ROOT=1192939 (18.5.08); vollständiger Text auf der Seite betroffener Lehrerinnen: http://www. isgg.de/UrteilDorisGraber.pdf (17.3.08). Pero esa sentencia fue anulada por el Tribunal Administrativo del Land de Baden-Württemberg, con sede en Manheim, (Verwaltungsgerichtshof-VGH), 14.05.2008, Az. 4 S 516/07, prohibiéndole usar el velo en aplicación de la Ley del Land: vgl. http://www.vghmannheim. de/ servlet/PB/menu/1219974/index.html?ROOT =1153033 (8.6.08). Sobre esta última sentencia ver, «Muslimische Lehrerin darf keine Koptuch tragen», Welt, n 24, 2008. https://www.welt.de/politik/ article1812515/Muslimische-Lehrerin-darf-kein-Kopftuch-tragen.html (Consultado 7 de junio de 2017). La mencionada profesora trabajaba en un colegio en el que el 60\% de los alumnos son inmigrantes. $\mathrm{Ha}$ dado clases durante 16 años con velo hasta su jubilación. Ver entrevista en 2015, realizada por HÖFLE, N. (2015). «Die Menschen sehen nur die Kopftuch», SZ, 18 marzo 2015. 


\section{VII.4. El artículo 7 párrafo 1 y artículo 12.3 de la Constitución de Renania del Norte Westfalia}

El BVerfG examinará la conformidad del inciso 3 de este artículo 57 de la Ley de Educación de RNW, pero para ello hace una interpretación sistemática de este artículo en relación con el artículo 7 de la propia Constitución del Land de RNW y a su vez de éste con la $\mathrm{LF}^{164}$. Para entender el contexto de este examen, hay que tener en cuenta que la Administración del Land utiliza la propia Constitución del Land de RNW como argumento a favor de la constitucionalidad del polémico inciso referente a los valores cristiano-occidentales para privilegiar estos en la escuela pública, que en su artículo 7 dice literalmente:

«1. Despertar el temor de Dios, el respeto de la dignidad humana y la disposición para la acción social es el propósito principal de la educación.

2. Los jóvenes deben ser educados en el espíritu de la humanidad, la democracia y la libertad, la tolerancia y el respeto de las convicciones de los demás, en la responsabilidad para con los animales y la conservación de los recursos naturales, en el amor por la gente y la tierra, a la Comunidad internacional y una mentalidad pacífica».

El problema a examen, no es el hecho de que la Constitución del Land utilice este principio y la referencia a Dios, sino que el inciso 3 de la LSchulG se apoye en él para tratar de un modo diferente a los profesores cristianos y judíos, frente a los de otras religiones.

El Tribunal Federal de Trabajo había entendido que el inciso 3 no era discriminatorio porque en realidad cuando en ese Land se habla de los valores cristianos son unos valores que deben ser entendidos en cuanto ya están secularizados («...soll sich diez auf säkularisierte Werte des Christentums beziehen»). El temor de Dios no debe ser entendido sólo como el Dios cristiano, sino que deben de tener cabida otras religiones como la islámica, o las politeístas o las que tienen una visión impersonal de $\operatorname{Dios}^{165}$. El BVerfG no va a admitir esa interpretación para amparar la constitucionalidad del inciso 3 del art. 57.4 de la LSchulG. Del hecho de que el art. 7 de la Constitución de RNW sea conforme a la Constitución alemana, no se puede inferir que la cláusula de privilegio sea constitucional. En suma, para el BVerfG la interpretación de este artículo de la Constitución del Land no justifica el art. 57. 4. inciso 3 de la Ley de Educación de RNW, porque la LF no autoriza un trato discriminatorio entre las obligaciones de los profesores basado en su pertenencia a diferentes religiones. De

164 BVerfG, 27.01.2015, 1 BvR 471/ 101 BvR 1181/10, § 130.

165 Citados por el propio Tribunal: ENNUSCHAT, J. (2002), en LÖWER/TETTINGER, Kommentar zur Verfassung des Landes Nordhrein-Westfalen, Art. / Rn. 23 m.v.N., Art. 12 Rn.22; DÄSTER, U. (2002). Die Verfassung des Landes Nordbrein-Westfalen, 2, Art. 7.3; SÖBBEKE, M. in Heusch/ Schönenbroicher, Die Landesverfassung Nordrhein-Westfalen, 2010, Art. 12 Rn. 10; HÄBERLE, P. (1987). in Festchrift für Wolfgang Zeidler, Bd. 1, S.3 <14> 
manera que el derecho de un Land no puede ir contra el derecho constitucional (art. 31 de la LF), ni reducir los derechos de libertad religiosa contemplados en la LF. Con esto el TC está haciendo uso de su competencia de control de constitucionalidad de las leyes de los Länder.

Por otra parte, el TC no puede forzar una interpretación distinta de un texto cuya interpretación literal es clara y que responde a la intención del legislador democrático del Land. Luego no cabe que el TC haga una interpretación nueva de algo que tiene un sentido unívoco, porque sería hacer de legislador, por lo tanto sólo le queda anularlo ${ }^{166}$. La interpretación que ha hecho el Tribunal Federal de Trabajo pretendiendo hacerlo compatible con la LF no es posible ${ }^{167}$. Nos referimos a la pretendida distinción de que estos valores cristianos están ya normativizados en la LF y que por tanto su validez es independiente de su fundamento religioso, aunque se use el término «cristiano» ${ }^{168}$. A lo que se añade que es un argumento insostenible la presunción de que quienes usan símbolos cristianos lo hacen como parte de una tradición y no con un significado individual. El BAG y el gobierno del Land pretenden establecer la tesis de que los profesores que utilicen símbolos cristianos lo hacen no de un modo personal, sino siguiendo una tradición del Land, de manera que esos símbolos no se deberían equiparar con la expresión de un compromiso individual. Es decir habría símbolos religiosos que entrarían en la prohibición del inciso 1, pero los símbolos cristianos-occidentales usados por los profesores estarían permitidos porque responderían a la tradición de los valores del Land (según el inciso 3) y quienes los usan no le dan un significado individual. En este presunto razonamiento, que es bastante sinuoso, se dan varios saltos lógicos.

El gobierno del Land pretende justificar la constitucionalidad del inciso, ya que en las discusiones parlamentarias ${ }^{169}$ se tuvo en cuenta que un Land vecino, el Land de Baden-Württemberg había legislado una reforma de un artículo de la Ley de Educación para prohibir el velo en las maestras ${ }^{170}$. Con posterioridad a la sentencia del caso Ludin y a raíz de la introducción de esa nueva norma, esta profesora fue finalmente despedida. En su nuevo recurso al Tribunal Federal Administrativo ${ }^{171}$, el BVerwG dio esa nueva norma del Land por constitucional y consideró el despido como procedente. El Parlamento de RNW se apoyó en este hecho para considerar que su proyecto de Ley también era constitucional ${ }^{172}$.

\footnotetext{
166 BVerfG, 27.01.2015, 1 BvR 471/ 101 BvR 1181/10, §132.

167 BVerfG, 27.01.2015, 1 BvR 471/ 101 BvR 1181/10, §131.

168 BVerfG, 27.01.2015, 1 BvR 471/ 101 BvR 1181/10, §133.

169 BVerfG, 27.01.2015, 1 BvR 471/ 101 BvR 1181/10, \$134.

170 SchulG BW, § 38 Abs. 2

171 BVerwGE 121, $140<147,150>, 26.06 .2004$.

172 LT- Vorlage 14/463, p. 2 y LTDrucks 14/569, p. 7.
} 


\section{VII.5. Los trabajos legislativos previos}

Para entender la intención del Legislador del Land es imprescindible recurrir a los trabajos legislativos preparatorios. No queda duda al estudiarlos de que el Parlamento no quería prohibir ni la Kipá judía, ni el hábito religioso ${ }^{173}$, sino exclusivamente el velo de las mujeres musulmanas. Se afirma explícitamente: «En este contexto, en el futuro el uso de un velo islámico en el aula es inadmisible de acuerdo con al art. 57 párrafo 4 de la Ley de la Escuela de Renania del Norte Westfalia porque al menos una parte significativa de sus defensores consideran que la mujer ocupa una posición inferior en la sociedad, en el Estado y en la familia o mantienen una postura fundamentalista a favor de un gobierno teocrático que está en contradicción con los valores constitucionales de la República Federal alemana y de Renania Westfalia» ${ }^{174}$. Además, en los trabajos preparatorios se evitó hacer una referencia explícita al art. 12 de la Constitución de RNW en la que se afirma que la escuela pública estará abierta a otras confesiones religiosas. Todo ello indica que el Parlamento era consciente del riesgo de inconstitucionalidad de ese inciso, pero que explícitamente no quiso hacer una interpretación distinta que fuera compatible con la LF.

El hecho de que la redacción del texto fuera finalmente ambigua se hizo intencionadamente y la definición que figura en el texto prelegislativo fue deliberada, expresando la intención del legislador autonómico de prohibir el velo, en una interpretación sistemática del inciso 3 con el inciso 1. Es decir, no cabe una interpretación favorable al uso del velo islámico. Y así lo interpretó el Tribunal Federal de Trabajo dando por válida la norma y por procedentes los dos despidos.

Pero el Tribunal Federal de Trabajo hizo una interpretación que no es conforme con la LF porque viola los derechos constitucionales contemplados en el art. 4. Párrafo 1 y 2 de la LF, lo que no puede justificarse porque conduce a la discriminación por razones religiosas (gleichbeitswidrigen Benachteiligung aus Glaubensgründen): el BVerfG así lo entiende y por ello los fallos que se han basado en ese inciso inconstitucional se anulan también ${ }^{175}$.

En relación con el artículo 57 párrafo 4, inciso 3 de la Ley de la escuela de Renania del Norte Westfalia, el TC considera que es discriminatorio contra los miembros de otras religiones, al permitir sólo el uso de símbolos cristianos u occidentales y es contrario a los artículos 3 de la LF, sobre igualdad y no discriminación y contrario al

173 LT- Vorlage 14/463, p. 2 y LTDrucks 14/569, p. 9.

${ }^{174}$ LT- Vorlage 14/463, p. 2 y LTDrucks 14/569, p. 8: «Vor diesem Hintergrund ist das Tragen eines muslimischen Kopftuchs im Unterricht künftig gemäß $\$ 57$ Abs. 4. SchulG unstatthaft, weil zumindest ein nicht unerheblicher Teil seiner Befürworter damit eine mindere Stellung der Frau in Gesselschaft Staat und Familie oder eine fundamentalistiche Stellungsnahme für ein theokratischer Staatswesen im Widerspruch zu den Verfassungswerten in der Bundesrepublik Deutschland und in Nordrhein-Westfalen verbindet».

175 BVerfG, 27.01.2015, 1 BvR 471/ 101 BvR 1181/10, §137. 
artículo 33 LF del acceso en igualdad a la función pública. En la práctica, las personas que se han visto afectadas por esa normativa (y la de los otros Länder) han sido sólo mujeres musulmanas, de hecho la jurisprudencia es abundante.

En relación con el inciso 3 del párrafo 4 del artículo 57 de la ShuldG, el Tribunal de trabajo del Land interpretó que la «representación» o «expresión» de valores educativos y culturales cristianos y occidentales no es equiparable a un compromiso individual como el que denotaría el uso de otro tipo de vestimentas a las que se refiere el inciso 1.

Presumir una falta de idoneidad en el acceso a la función pública por mantener unas convicciones religiosas es contrario al art. 33 de la GG. Al empleado debe juzgársele por sus actos concretos y cuando de hecho no respete o enseñe contra los valores constitucionales o viole los derechos de los alumnos.

Por ello el BVerG declara el inciso 3 del $\$ 57$ párrafo 4 sin efecto e incompatible con el art. 3.3.1 LF y con el art. $33 \mathrm{LF}$, mientras que considera constitucionales el resto del artículo y el $\S 58$ inciso 2 de la citada Ley ${ }^{176}$. El inciso 1 no viola la igualdad de trato por razón de sexo y es conforme con la LF si se hace una interpretación restrictiva $^{177}$. Sin embargo, que el legislador atribuya como declaraciones religiosas y determinadas intenciones sólo a la apariencia externa es contrario al principio de igualdad de trato.

\section{CONCLUSIONES}

Esta decisión pone los medios para finalizar con una clara discriminación contra las mujeres musulmanas, especialmente de nacionalidad alemana, que desean acceder a la enseñanza pública como maestras y desean usar velo durante el desempeño de su trabajo en el centro escolar.

En relación con los pasos que exige la ponderación, el BVerfG realiza adecuadamente la mayoría de ellas. Comenzando por el examen de la adecuación o idoneidad de los supuestos de hecho, los califica como protegidos constitucionalmente. También se esfuerza por aportar pruebas empíricas. Para ello comienza con una adecuada elección de las normas aplicables al caso, especialmente los DF constitucionales, colocando en un lado de la balanza los derechos de libertad religiosa negativa de los alumnos, el derecho de los padres, la misión educativa de la escuela, la neutralidad positiva del Estado en relación con las diversas confesiones. En el otro lado de la balanza sitúa los derechos de las profesoras, entre las que incluye el derecho de libertad religiosa positiva, el acceso en igualdad a la función pública y el derecho a no ser discriminado por motivo de religión, sexo o raza, todo ello en el contexto de una neutralidad positiva del Estado. El BVerfG hace una interpretación del contenido esencial de cada uno de

176 BVerfGE 108, 282, § 138

177 BVerfGE 108, 282, §142. 
esos derechos y de sus límites. Su visión de la neutralidad del Estado como una neutralidad abierta condiciona la ponderación de los derechos en juego, en los dos lados de la balanza. En cuanto a la interpretación dogmática de estos derechos, el segundo senado del BVerfG sigue bastante de cerca la dogmática constitucional sin separarse de ella. Su interpretación de la neutralidad del Estado como abierta está en consonancia con la dogmática anterior, con excepción de lo afirmado en la sentencia del caso Ludin.

El BverfG respeta las reglas de la argumentación racional y evita dar saltos lógicos. Pone en evidencia las inferencias indebidas tanto del art. 57. 4 de la SchulG de RNW, como de la interpretación inadecuada del art. 4.2 de la LF realizada por las instancias judiciales anteriores. Si llevar símbolos religiosos por parte de funcionarios está amparado en el art.4.2 de la LF, la existencia de una ley prohibitiva (sólo del uso del velo islámico por parte de las profesoras) basada en el peligro abstracto no convierte la decisión del legislador en legal, porque se sentaría una ley prohibitiva discriminatoria, basada sólo en prejuicios previos no demostrados empíricamente, ya que no hay pruebas científicas de una influencia negativa del uso del velo por parte de las profesoras en los alumnos en general, y tampoco en este caso en concreto. En cuanto a la interpretación del principio de neutralidad del Estado, que es clave a lo largo de toda la decisión y en su fallo, realiza una adecuada interpretación del mismo conforme a la Ley Fundamental de Bonn, cuyo modelo de relación entre el Estado y las confesiones es de una neutralidad abierta y positiva, de cooperación y acuerdos con las diversas confesiones, de un secularismo abierto y no laicista porque un modelo de neutralidad distanciada de las religiones no sería el defendido por la LF.

En definitiva, esta nueva decisión del primer senado del BVerfG aplica correctamente el principio de la proporcionalidad estricta. Primero porque establece adecuadamente que el grado de insatisfacción de la paz escolar o de los derechos de los padres debe medirse a la vista de conflictos reales. En caso de no existir peligro real para la paz escolar que impida ejercer la tarea educativa del Estado, no se daría una lesión de los derechos de los alumnos, ni de los padres. La sola presencia del velo no colisiona automáticamente con los derechos de libertad religiosa de los alumnos. Segundo porque al examinar la importancia de satisfacer el derecho de libertad religiosa de las profesoras y las consecuencias negativas de la ley prohibitiva del Land juzga que ello supone una lesión grave y con una medida desproporcionada e innecesaria. En principio, la importancia de satisfacer el derecho de libertad religiosa, no justifica que la protección de la paz escolar exija la prohibición del uso del velo por parte de las profesoras. El BverfG formula un juicio racional suficiente sobre la intensidad de la interferencia en la restricción de la libertad religiosa positiva si se legisla una norma prohibitiva, calificándola de 'grave', y no otorga a la paz escolar suficiente peso o grado de importancia como para promulgar una ley prohibitiva por la voluntad del legislador del Land. Formula un juicio racional suficiente sobre la intensidad de la interferencia en la restricción de la libertad positiva religiosa de las profesoras, en el caso de la formulación prohibitiva del art. 57. inciso 3 de la SchulG de RNW, cali- 
ficando este inciso de la norma como una injerencia grave en ese DF y anulándolo por contrario a la LF. Una Ley prohibitiva general basada en un peligro abstracto es contraria a la LF y una injerencia desmedida en un DF porque no permite la ponderación del caso concreto.

Por ello, en el tercer paso se concluye que la importancia de satisfacer los derechos de las profesoras justifica que ceda la libertad negativa religiosa de los alumnos y que prevalezca la liberta religiosa positiva. Con la excepción de casos en los que haya conflictos reales y en los que otros medios alternativos de resolución de conflictos no hayan resultado de momento eficaces a corto plazo, en los que transitoriamente se permitirían medidas prohibitivas en ese lugar concreto, siendo deseable la búsqueda de soluciones armonizadas o de concordancia práctica, en suma de cualquier ajuste o acomodamiento razonable. En estos casos, ponderadas las circunstancias cabrían ciertas prohibiciones temporales transitorias del uso del velo en lugares concretos, dictados por la autoridad escolar del centro o de un reglamento, extremo que no hemos considerado como adecuado por nuestra parte.

Title:

The Balancing and the open neutrality against the religious and racial discrimination in the sentence of the German Constitutional Court of 2015 about the use of the headscarf by teachers

\section{Summary:}

I. Introduction. The social context in which the German Federal Constitutional Court takes this decision. II. The argumentation in the decision of the German Constitutional Court in 2015 about the use of headscarfs by school teachers. III. The facts and the Education Law of North Rhine Westphalia. IV. The legal arguments of the Constitutional Court. V. The Rights of the Plaintiffs. V.1. The right to religious freedom and the use of religious garments in that space. V.2. The equal access to be civil servant and the discrimination of Muslim women. VI. The other side of the weigh scale: the Rights of the third parties. Examination of the limits to fundamental rights in the present case. Concrete danger versus abstract danger. VI.1. The negative religious liberty of pupils and the limit of prohibition of indoctrination by teachers. VI.2. The right of parents (art. 6.1. German Constitution). VI.3. The open neutrality principle in the public education and the equal treatment of religions. VII. The examination of the constitutionality of the art. 57 of the North Rhine Westphalia 
Education Law. VII.1. Restrictive interpretation of subsection 1 of the art. 57.4. It can be used only when facing concrete danger. VII.2. Analysis of the subsection 2 of the article 57.4 of the education law of North Rhine Westphalia. VII.3. The clause of the privilege of the Western Christian values of art. 57.4 .3 of the education law. VII.4. Discussion on the art. 7 paragraph 1 and art. 12.3 of the Constitution of North Rhine Westphalia. VII.5. The previous legislative drafts. VIII. Conclusions.

\section{Resumen:}

El artículo analiza la decisión del Tribuna Constitucional Federal alemán de enero de 2015, relacionado con dos recurso de amparo de dos maestras musulmanas que querían usar el velo durante el ejercicio de su trabajo en la escuela. El BVerfG anulará un inciso del art. 57.4 de la Ley de educación del Land de Renania del Norte-Westfalia, que prohibía a las profesoras el uso del velo, mientras que permitía el uso de símbolos religiosos cristianos y judíos, por considerarlo contrario al derecho constitucional de libertad religiosa (art. 4 de la LF), art. 3 LF, al derecho de igualdad de trato y no discriminación por religión y por raza (art. 3. LF), y contrario a la igualdad en el acceso al funcionariado (art. 33 LF). Esta decisión está teniendo una gran repercusión cara a la inclusión de los ciudadanas musulmanes con origen en la inmigración en la sociedad alemana. Reflejaremos las consecuencias legales y la aplicación inmediata de esta doctrina en tribunales inferiores. El estudio se centra en el empleo que el BVerfG realiza de las técnicas de la argumentación jurídica, la ponderación, el principio de proporcionalidad, y principio de concordancia práctica, para resolver los derechos fundamentales en conflicto. El BVerfG realiza una utilización innovadora en la ponderación de los DF, por un lado los derechos referentes a las maestras, como son la igualdad de trato y paridad de las religiones en un contexto social de un creciente pluralismo religioso, el principio de no discriminación por religión, la igualdad de acceso al funcionariado, la no discriminación de las mujeres. En el otro lado de la balanza, se situarán; el derecho de libertad religiosa de los alumnos y el derecho de educación de los padres, así como el mandato constitucional educativo de la escuela y el principio de la paz escolar. El BverfG apostará por un modelo constitucional de defensa de la neutralidad abierta del Estado hacia las religiones, reforzando el modelo vigente de separación con cooperación amistosa, pero insistiendo en la necesidad de una nueva apertura y flexibilización hacia la presencia de las religiones minoritarias, concediendo a éstas el mismo trato jurídico que a las religiones de mayor tradición histórica en el país (neutralidad abierta hacia todas las religiones, Toleranzslösung), a su vez con respeto a la historia y a la tradición alemana, y rechazando un modelo de neutralidad estricta o de distancia con las religiones, (strenge Neutralität Lösung o Distanz Neutralität), separándose de la sentencia del segundo senado del BVerfG, en el caso Ludin de 2003, que dejaba esta opción como posible. La nueva decisión del primer senado rechaza también un modelo de cooperación (neutralidad positiva), pero que privilegiara las confesio- 
nes cristianas (protestantes y católicas) o la cultura dominante (Deutsche Leitkultur) lo que acabaría en un retorno a una cierta confesionalidad de Estado. El fallo concluye que una ley general prohibiendo el uso del velo a las profesoras en las escuelas públicas alemanas sería contrario a la LF y que sólo se podría prohibir en los casos concretos en que ello represente un peligro real en unas determinadas circunstancias y no por un peligro meramente abstracto, otorgando el amparo constitucional a las dos recurrentes.

\section{Abstract:}

The article analyzes the decision of the German Federal Constitutional Court in January of 2015, related to two constitutional appeals of two Muslim teachers who wanted to use the veil during the exercise of their work in the school. The BVerfG will annul a paragraph of art. 57.4 of the Education Act of the Land of North Rhine-Westphalia, which prohibited teachers from wearing the headscarf, while permitting the use of Christian and Jewish religious symbols, as contrary to the constitutional right to religious freedom (art. 4 of the German Constitution), art. 3 GC, the right to equal treatment and non-discrimination by religion and by race (Article 3 GC), and contrary to equality in access to civil servants (Article $33 \mathrm{GC}$ ). This decision is having a great impact in the inclusion in the German society of the Muslim women citizens with origin in the immigration. The article reflects the legal consequences and the immediate application of this doctrine in lower courts. The study focuses on the use that the BVerfG makes of the techniques of legal argumentation, weighting, proportionality principle, and principle of practical agreement, to resolve fundamental rights in conflict. The BVerfG makes an innovative use in the weighting of the DF, on the one hand the rights related to teachers, such as equality of treatment and parity of religions in a social context of growing religious pluralism, the principle of non-discrimination by Religion, equal access to civil service, non-discrimination of women. On the other side of the balance, they will be placed; the right of religious freedom of the pupils and the right of education of the parents, as well as the constitutional educational mandate of the State and the principle of school peace. The BVerfG will bet on a constitutional model to defend the open neutrality of the State towards religions, reinforcing the current constitutional model of separation with friendly cooperation, but insisting on the need for a new opening and flexibility towards the presence of minority religions, granting (Neutrality open to all religions, Toleranzslösung), in turn with respect to German history and tradition, and rejecting a model of strict or distance neutrality with the religions, (strenge Neutralität Lösung or Distanz Neutralität), separating from the sentence of the second senate of the BVerfG, in the Ludin case of 2003, which left this option as possible. The new decision of the first senate also rejects a model of cooperation (positive neutrality), but that privileges Christian (Protestant and Catholic) confessions or the dominant culture (Deutsche Leitkultur) which would end in a return to a certain confesionalidad of State. The ruling concludes 
that a general law prohibiting the use of the headscarf to the teachers in the German public schools would be contrary to the GC and that could only be prohibited in the concrete cases in which it represents a real danger in certain circumstances and not by a purely abstract danger, granting the constitutional protection to the two appellants.

\section{Palabras clave:}

Decisión Tribunal Constitucional Federal alemán 2015, uso velo islámico por maestras, acceso en igualdad al funcionariado, no discriminación por razón de religión y raza, neutralidad abierta colegios públicos, libertad religiosa funcionarios, símbolos religiosos en maestros, libertad religiosa negativa padres y alumnos, mandato educativo del Estado, Ley educación Renania del Norte-Westfalia, ponderación DF, integración de ciudadanos musulmanes en Alemania.

\section{Key words:}

German Constitutional Court Decision of 2015, use of muslim women headscarf by teachers, Right to equality in access to the civil servant position, no discrimination based in religión and race, open neutrality in public schools, religious freedom of teachers civil servants, religious symbols in teachers, negative religious freedom in pupiles, educative mandate of the State, Education Law of Norhrein-Westfalen, balancing of Fundamental Rights, integration of Muslim Citizens in Germany. 